\title{
Volcanic Plume Impact on the Atmosphere and Climate: O- and S-Isotope Insight into Sulfate Aerosol Formation
}

\section{Erwan Martin}

Sorbonne Université, CNRS-INSU, Institut des Sciences de la Terre Paris, ISTeP UMR 7193, F-75005 Paris, France; erwan.martin@sorbonne-universite.fr; Tel.: +33-144-274-181

Received: 4 May 2018; Accepted: 26 May 2018; Published: 31 May 2018

\begin{abstract}
The impact of volcanic eruptions on the climate has been studied over the last decades and the role played by sulfate aerosols appears to be major. S-bearing volcanic gases are oxidized in the atmosphere into sulfate aerosols that disturb the radiative balance on earth at regional to global scales. This paper discusses the use of the oxygen and sulfur multi-isotope systematics on volcanic sulfates to understand their formation and fate in more or less diluted volcanic plumes. The study of volcanic aerosols collected from air sampling and ash deposits at different distances from the volcanic systems (from volcanic vents to the Earth poles) is discussed. It appears possible to distinguish between the different S-bearing oxidation pathways to generate volcanic sulfate aerosols whether the oxidation occurs in magmatic, tropospheric, or stratospheric conditions. This multi-isotopic approach represents an additional constraint on atmospheric and climatic models and it shows how sulfates from volcanic deposits could represent a large and under-exploited archive that, over time, have recorded atmospheric conditions on human to geological timescales.
\end{abstract}

Keywords: volcanic sulfate aerosols; oxygen and sulfur multi-isotopes; atmospheric chemistry

\section{Introduction}

Globally on Earth, each year, volcanoes release an average of 10-20 Mt of sulfur-bearing gases, and occasionally much more during super eruptions (e.g., [1,2]). Atmospheric sulfur plays a paramount role in the terrestrial radiative balance. Consequently, determining its source and understanding its physico-chemical transformations and fate in the atmosphere appear crucial in predicting its impact on the atmosphere and climate. Indeed, when released into the atmosphere S-bearing gases (mainly $\mathrm{SO}_{2}$ : $\leq 25 \% ; \mathrm{H}_{2} \mathrm{~S}: \leq 10 \%$; and $\mathrm{COS}$ and $\mathrm{CS}_{2:} \leq 0.01 \%$ of the volume of the emitted gases; [3-5] and references therein) are oxidized, being thus transformed into sulfate aerosols that directly and indirectly lead to a negative radiative forcing. First, sulfate aerosols directly reflect part of the solar radiations, thus decreasing the amount of sun energy reaching the Earth's surface. On the other hand, sulfate aerosols absorb part of the incoming solar radiation in the IR wavelengths and this results in a warming of the aerosol-bearing atmospheric layer associated to a temperature decrease between it and the Earth's surface. Additionally, volcanic aerosols play the role of cloud nucleation leading to more cloud formation, which reinforces the albedo and therefore causes the Earth's surface to cool (e.g., [6,7]). Such "volcanic winters", that can be more or less severe and global depending on the strength and location of the eruption, have been observed after several major eruptions such as those at Mt Agung in 1963, El Chichón in 1983, and Pinatubo in 1991 (e.g., [8-11]).

Atmospheric modeling aims at predicting climate evolution on Earth. However, including the sulfur volcanic aerosol formation processes would increase the models' accuracy regarding the volcanic forcing climate. This paper discusses the use of oxygen and sulfur multi-isotopes in improving our 
understanding of sulfate aerosol formation, fate, and sources. The ${ }^{18} \mathrm{O} /{ }^{16} \mathrm{O}$ and ${ }^{17} \mathrm{O} /{ }^{16} \mathrm{O}$ as well as ${ }^{34} \mathrm{~S} /{ }^{32} \mathrm{~S},{ }^{33} \mathrm{~S} /{ }^{32} \mathrm{~S}$, and ${ }^{36} \mathrm{~S} /{ }^{32} \mathrm{~S}$ are measured and expressed as $\delta^{18} \mathrm{O}$ and $\delta^{17} \mathrm{O}$ as well as $\delta^{34} \mathrm{~S}, \delta^{33} \mathrm{~S}$ and, $\delta^{36} \mathrm{~S}$ respectively (Equation (1)). During any process, the isotopes fractionate, changing the isotopic ratios, depending on the mass differences between heavy and light isotopes. For instance, the mass difference between ${ }^{18} \mathrm{O}$ and ${ }^{16} \mathrm{O}$ is twice as much as between ${ }^{17} \mathrm{O}$ and ${ }^{16} \mathrm{O}$, leading to the relation ${ }^{17} \mathrm{O} /{ }^{16} \mathrm{O} \sim 0.5^{* 18} \mathrm{O} /{ }^{16} \mathrm{O}$, commonly expressed as $\delta^{17} \mathrm{O}=\left(\delta^{18} \mathrm{O}+1\right)^{0.524}-1$. This very widespread rule suffers some exceptions, where isotopic fractionation does not depend on the mass differences between isotopes, it is referred to as Mass Independent Fractionation (MIF) (e.g., [12-15]). The difference to the isotopic mass dependent fractionation relation is quantified by $\Delta^{17} \mathrm{O}, \Delta^{33} \mathrm{~S}$ and $\Delta^{36} \mathrm{~S}$ (Equations (2)-(4)). Therefore, isotopic mass dependent fractionation results in a $\Delta=0 \%$ whilst MIF has $\Delta \neq 0 \%$.

$$
\begin{gathered}
\delta \mathrm{A}=\left(\mathrm{R}_{\mathrm{A}} / \mathrm{R}_{\mathrm{st}}\right)-1 \text {; for instance } \delta^{18} \mathrm{O}=\left({ }^{18} \mathrm{O} /{ }^{16} \mathrm{O}_{(\text {sample })} /{ }^{18} \mathrm{O} /{ }^{16} \mathrm{O}_{(\text {standard })}\right)-1 \\
\Delta^{17} \mathrm{O}=\delta^{17} \mathrm{O}-\left[\left(\delta^{18} \mathrm{O}+1\right)^{0.524}-1\right] \\
\Delta^{33} \mathrm{~S}=\delta^{33} \mathrm{~S}-\left[\left(\delta^{34} \mathrm{~S}+1\right)^{0.515}-1\right] \\
\Delta^{36} \mathrm{~S}=\delta^{36} \mathrm{~S}-\left[\left(\delta^{34} \mathrm{~S}+1\right)^{1.89}-1\right]
\end{gathered}
$$

considering that: $\delta A$ : isotopic composition of a sample $\left(e . g ., \delta^{18} \mathrm{O}\right) ; R_{A}$ : isotope ratio of the measured sample (e.g., $\left.{ }^{18} \mathrm{O} /{ }^{16} \mathrm{O}\right)$; Rst: isotope ratio of a standard. The mass dependent coefficients $0.524,0.515$, and 1.89 are from references $[16,17]$.

In the atmosphere, sulfate aerosols are generated by oxidation of S-bearing gases through different possible reactions or channels (Ch1, Ch2, Ch3, and Ch4; e.g., [18]). The multi O-isotopic composition of the different atmospheric oxidants is relatively well-known such that the resulting sulfate composition can be estimated for each oxidation channel (Figure 1). Therefore, coupling O- and S-isotopic composition with atmospheric chemistry allows the oxidation channel(s) from which they formed to be retraced. This not only helps to elucidate the sulfate aerosol formation in the atmosphere but also permits us to probe into the composition of the atmosphere and more specifically its oxidant capacity during specific volcanic eruptions.

$$
\begin{array}{ll}
\text { Ch1: } & \| \begin{array}{l}
\mathrm{SO}_{2}+\mathrm{OH}+\mathrm{M} \rightarrow \mathrm{HOSO}_{2}+\mathrm{M} \\
\mathrm{HOSO}_{2}+\mathrm{O}_{2} \rightarrow \mathrm{SO}_{3}+\mathrm{HO}_{2} \\
\mathrm{SO}_{3}+\mathrm{H}_{2} \mathrm{O}+\mathrm{M} \rightarrow \mathrm{H}_{2} \mathrm{SO}_{4}+\mathrm{M}
\end{array} \\
\text { Ch2: } & \mathrm{SO}_{2(\mathrm{aq})}+\mathrm{H}_{2} \mathrm{O}_{2} \rightarrow \mathrm{H}^{+}+\mathrm{SO}_{4}^{2-}+\mathrm{H}_{2} \mathrm{O} \\
\text { Ch3: } & \mathrm{SO}_{2(\mathrm{aq})}+\mathrm{O}_{3} \rightarrow \mathrm{H}^{+}+\mathrm{SO}_{4}^{2-}+\mathrm{O}_{2} \\
\text { Ch4: } & \mathrm{SO}_{2(\mathrm{aq})}+\frac{1}{2} \mathrm{O}_{2} \stackrel{\mathrm{TMI}}{\rightarrow} \mathrm{SO}_{4}^{2-}
\end{array}
$$

where M: any inert molecule that removes excess energy without participating in the reaction; TMI: transition metal ion; for (Ch4); $\mathrm{SO}_{2(a q)}$ is in aqueous phase and can be present as $\mathrm{SO}_{2} \cdot \mathrm{H}_{2} \mathrm{O}, \mathrm{HSO}_{3}^{-}$, or $\mathrm{SO}_{3}^{2-}$ (for $\mathrm{pH}$ from 2 to 7, which is most likely the case in volcanic plumes, $\mathrm{HSO}_{3}^{-}$dominates). Ch1, Ch2, Ch3 and Ch4 are the same as in Figure 1.

This isotopic approach opens new perspectives when considering volcanic deposits formed by different eruptions all around the world during the whole history of Earth. As volcanic activity has always been present, sulfates from volcanic deposits represent an underexploited archive that, over time, has recorded atmospheric conditions on human to geological timescales.

This paper reviews the different methods used for sulfate aerosol sampling, as well as for O- and S-isotopic measurements, the final purpose being a discussion of the mechanisms of formation of the volcanic sulfate during the different kind of volcanic eruptions, from passive degassing to large caldera-forming eruptions (super-eruptions). 


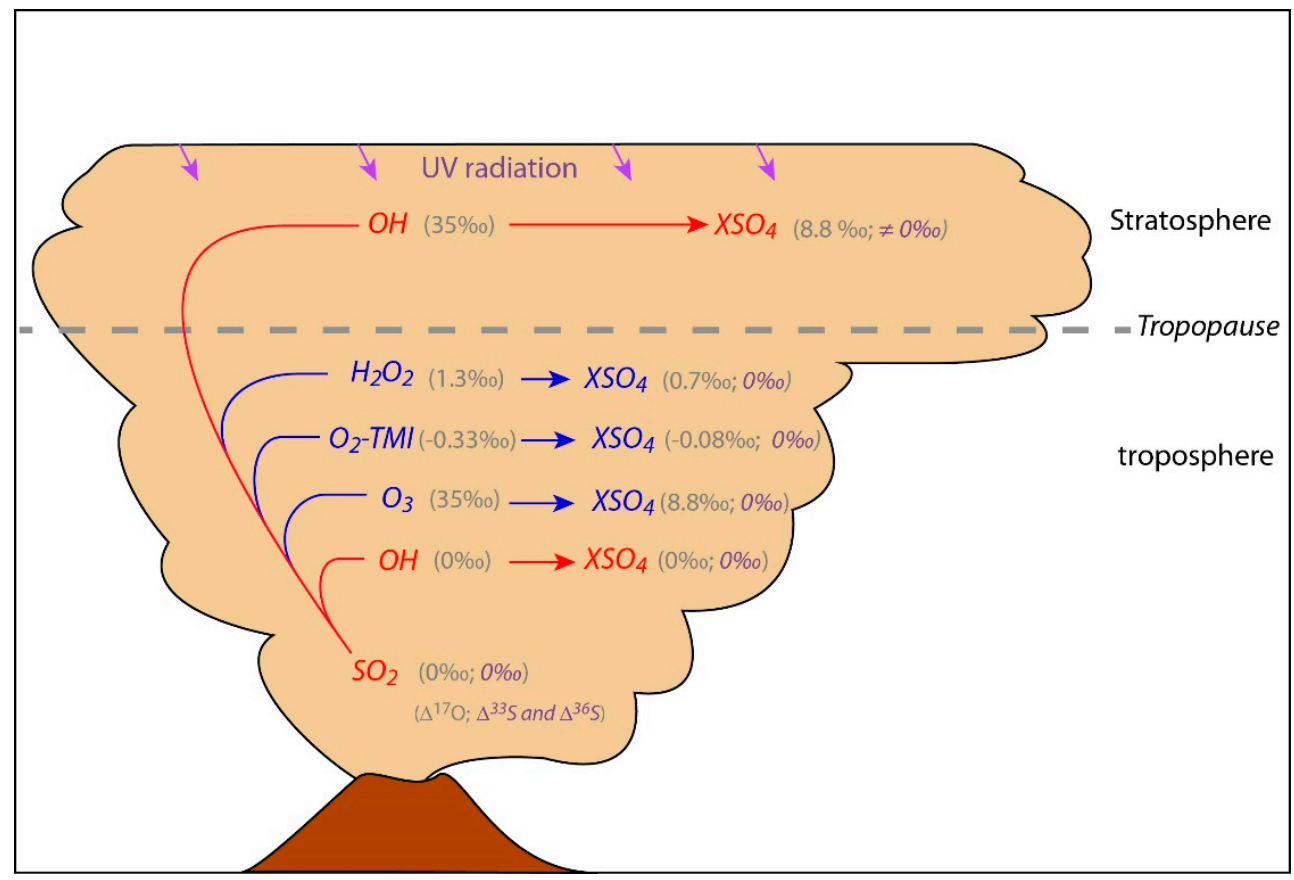

Figure 1. Volcanic $\mathrm{SO}_{2}$ main oxidation channels in the troposphere and stratosphere (gas phase reactions in red and aqueous reactions in blue). $X$ can be two monovalents or one bivalent cation (e.g., $\mathrm{H}^{+}, \mathrm{K}^{+}, \mathrm{Na}^{+}$, or $\mathrm{Ca}^{2+}$ ). The average isotopic values of volcanic $\mathrm{SO}_{2}$, atmospheric oxidants and expected sulfates are indicated in grey values for $\Delta^{17} \mathrm{O}$ and purple for $\Delta^{33} \mathrm{~S}$ and $\Delta^{36} \mathrm{~S}$. The detailed oxidation reactions are discussed in the text (Ch1, Ch2, Ch3 and Ch4). Note that sulfate oxygen atoms come partially from the atmospheric oxidants, at $25 \%$ from $\mathrm{OH}$ in $\mathrm{Ch} 1,50 \%$ from $\mathrm{H}_{2} \mathrm{O}_{2}$ in $\mathrm{Ch} 2,25 \%$ from $\mathrm{O}_{3}$ in for $\mathrm{Ch} 3$, and 25-50\% from $\mathrm{O}_{2}$ in $\mathrm{Ch} 4$ [19]. Using these proportions makes a theoretical estimation of sulfate $\Delta^{17} \mathrm{O}[20]$ possible. $\Delta^{33} \mathrm{~S}$ and $\Delta^{36} \mathrm{~S} \neq 0$ are generated mainly by $\mathrm{SO}_{2}$ photolysis and photoexcitation by UV radiation [12,21,22], process that can most likely take place in the stratosphere above the $\mathrm{O}_{3}$ layer, where UV radiations are not filtered. Note that in the troposphere $\Delta^{33} \mathrm{~S}$ and $\Delta^{36} \mathrm{~S}=0$ is expected but some mass dependent processes can generate small isotopic anomalies as discussed in the text (Section 3.2) and in Figure 3.

\section{Methods}

Several laboratories use a variety of methods to extract sulfate from natural samples and to analyze their isotopic composition. Some methods are still in development, nonetheless the present paper describes the methods classically used nowadays.

\subsection{Volcanic $\mathrm{SO}_{2}$ and $\mathrm{H}_{2} \mathrm{~S}$ Sampling}

Gas sampling at volcanic vents have been used for the last 40 years [23] and is based on the fact that acidic volcanic gases, including $\mathrm{SO}_{2}$ and $\mathrm{H}_{2} \mathrm{~S}$ can be trapped in alkaline solutions. The most quantitative method appears to be the Giggenbach bottle system [24], but it requires approaching the volcanic vent, making the sampling and isotopic characterization of volcanic S-bearing gases difficult. The Giggenbach bottle system consists of pumping the volcanic gases, which are collected into a bottle containing an alkaline solution. The acid gases are dissolved in the solution and the low solubility gases trapped in the headspace of the bottle. The development of such a method allows the simultaneous and separate collection of $\mathrm{SO}_{2}$ and $\mathrm{H}_{2} \mathrm{~S}[25,26]$. Indeed, both gases are trapped in the alkaline solution, but the presence of $\mathrm{Zn}$-acetate for instance leads to the immediate precipitation of $\mathrm{H}_{2} \mathrm{~S}$ into $\mathrm{ZnS}$, allowing the physical separation of sulfur from $\mathrm{SO}_{2}$ and $\mathrm{H}_{2} \mathrm{~S}$. This method is rather quantitative, which is necessary especially when isotopic analyses and mass balances are considered. Another method is based on passive alkaline traps, and consists simply of plastic beakers containing alkaline solution 
close the volcanic vents [27]. This method permits the volcanic gases to be collected over a longer period of time, allowing a better estimation of the average volcanic gas fluxes, but it does not allow the separation of different gases $\left(\mathrm{SO}_{2}\right.$ vs. $\mathrm{H}_{2} \mathrm{~S}$ for instance). Furthermore, during the absorption of S-bearing gases, some isotopic fractionation may occur, which may lead to a significant bias for isotopic studies [28]. Finally, filters soaked in alkaline solution are also used, but no separation of $\mathrm{SO}_{2}$ and $\mathrm{H}_{2} \mathrm{~S}$ is possible either and some isotopic fraction occurs when the $\mathrm{SO}_{2}$ flux is too high $[29,30]$.

\subsection{Sulfate Aerosol Sampling}

Air sampling and ash leaching are the two classic methods for collecting volcanic sulfates. The first method consists of pumping the air near volcanic vents; the particles (aerosols) are then gathered on filters, usually polytetrafluoroethylene (PTFE) filter packs (e.g., [29]). Pumps with a flow rate of about $30 \mathrm{~L} \mathrm{~min}^{-1}$ are generally used, as they are able to collect-in a few hours-enough sulfate aerosols for isotopic measurements [30,31]. Filters are then leached with deionized water in order to extract and concentrate sulfate aerosols into solution. Special care must be taken as, even if the reason is not yet fully understood, there is some variability in the $\delta^{18} \mathrm{O}$ measured in sulfates collected on filters [29,30]; this could be linked to the collecting method as it cannot be explained by any magmatic processes. However, this variability is not observed for $\Delta^{17} \mathrm{O}$ and S-isotopes. The other method for sulfate sampling consists of directly leaching volcanic ash. Indeed, a few tens to thousands of ppm of sulfate can be present in volcanic ash deposits (e.g., [32-34]). With the exception of barite ( $\left.\mathrm{BaSO}_{4}\right)$, sulfates are highly soluble in water, making their preservation in volcanic ash problematic or impossible in humid regions as well as in old volcanic deposits. Nevertheless, in arid to semi-arid environments, sulfates are at least partially preserved in volcanic ash layers up to tens of Ma [33,35]. Although the scavenging of sulfate is possible, isotopic exchange between water and sulfate is rather negligible in such environments [36]. Therefore, even if sulfate is partially removed by leaching or weathering from a volcanic deposit, its overall isotopic composition is preserved. In some cases, as in a sedimentary basin (an alkaline lake for instance), volcanic deposits can undertake the formation of authigenic sulfates that have a different isotopic composition compared to volcanic sulfates. Furthermore, long-term atmospheric deposition can also contribute to the sulfate from volcanic deposits, but it is rather negligible compared to the volcanic and authigenic sulfates [33]. The overall isotopic composition of sulfate from these volcanic deposits can possibly be progressively modified by dilution of the initial volcanic sulfate. However, using isotopic mixing models, it is possible to estimate the proportion of volcanic sulfate left in such deposits [33,35]. Deionized water is used for ash leaching and diluted $\mathrm{HCl}$ is added when carbonates were formed and could have trapped some sulfate. For efficient leaching, the preferred water/ash mass ratio is of about $1 / 20$ [37].

\subsection{Sulfate Chemical Composition and Preparation}

Even if the volcanic sulfate aerosol mineralogy is very complex and not totally understood, it appears that at volcanic vents, dominating sulfates are commonly K-Na-sulfates [38,39]. Considering the high volatility of $\mathrm{Na}$ and $\mathrm{K}$, the formation of these sulfate aerosol particles can be the result of the reaction between sulfuric acid and volatilized alkali-chlorides, the condensation of alkali-sulfate directly volatilized out of the magma or emitted by the hydrothermal system [40-43].

On the other hand, further away from the vent $(\geq 1-2 \mathrm{~km})$, where the plume is more diluted, it seems that Ca-sulfates dominate [38,39]. They are found as particles but also as well-formed crystals and coating on other particles such as volcanic ash. This testifies that Ca-sulfates are less likely to have been produced by mechanical aerosol formation like in volcanic conduits or vents. However, considering the low volatility of calcium, Ca-sulfates are most likely formed by the alteration of volcanic glass in the plume itself. This is also consistent with the fact that in volcanic deposits sampled far from the volcanic centers (between 5 and $25 \mathrm{~km} \mathrm{[30];} \geq 500 \mathrm{~km}[33,35]$ ), Ca-sulfates seem to be the dominant sulfate species. Ayris et al. [44] show that at high temperatures the high $\mathrm{Ca}^{2+}$ diffusivity in ash particles leads to $\mathrm{CaSO}_{4}$ formation in the volcanic conduit, which during the cooling down 
of the plume and its mixing with air, can be hydrated and generate gypsum as observed in volcanic ash deposits. However, in their experiments, K-Na-sulfates are not generated at high temperature by diffusion-driven mechanism. Therefore, this mechanism does not seem to explain the dominance of alkali-sulfate at volcanic vents.

In order to be able to measure the multi-isotopic composition of the collected sulfates, the latter is reacted with salts, which results in precipitates such as $\mathrm{BaSO}_{4}, \mathrm{Ag}_{2} \mathrm{SO}_{4}$, or $\mathrm{Ag}_{2} \mathrm{~S}$.

- $\quad \mathrm{BaSO}_{4}$ : For about 30 years (e.g., [36,45]) sulfates were transformed into highly insoluble $\mathrm{BaSO}_{4}$ by adding $\mathrm{BaCl}_{2}$ in the leachate obtained from different kind of samples such as ash or filters. However, when precipitated from a multi-anion solution, barite $\left(\mathrm{BaSO}_{4}\right)$ can occlude impurities such as nitrate, which can introduce an analytical bias in the measurement of O-isotopes [46]. For this reason, it is of paramount importance to purify the collected sulfate and make sure that no nitrate remains in the leachate. In order to purify barite, Bao et al. [47] developed the DDARP (diethylenetriaminepentaacetic acid dissolution and re-precipitation) method, while more recently, Le Gendre et al. [48] worked out a Resin Method for Sulfate Extraction and Purification (RMSEP), that passes the leachate solution through an anionic exchange resin, allowing the purification and concentration of sulfate. Then, by adding $\mathrm{BaCl}_{2}$, pure $\mathrm{BaSO}_{4}$ is precipitated.

- $\quad \mathrm{Ag}_{2} \mathrm{SO}_{4}$ : Via anionic exchange resins, sulfate from the leachate is converted into $\mathrm{Na}_{2} \mathrm{SO}_{4}$. Then $\mathrm{Ag}_{2} \mathrm{SO}_{4}$ is produced by passing the $\mathrm{Na}_{2} \mathrm{SO}_{4}$ through another resin conditioned into $\mathrm{Ag}^{+}$[49].

- $\quad \mathrm{Ag}_{2} \mathrm{~S}$ : Sulfate from leachate or $\mathrm{BaSO}_{4}$ or $\mathrm{Na}_{2} \mathrm{SO}_{4}$ is converted into $\mathrm{H}_{2} \mathrm{~S}$ (gas) via acid attack [50] in order to react with $\mathrm{AgNO}_{3}$ to finally precipitate and the sulfur as $\mathrm{Ag}_{2} \mathrm{~S}$ [51].

\subsection{Oxygen Isotope Measurements}

Oxygen isotope ratios were conventionally determined via graphite-reduction techniques that generate $\mathrm{CO}_{2}$ from the oxygen extracted from the sulfates [52,53]. However, due to an isobaric interference from ${ }^{13} \mathrm{C}$ (mass $45:{ }^{13} \mathrm{C}^{16} \mathrm{O}^{16} \mathrm{O}$ or ${ }^{12} \mathrm{C}^{16} \mathrm{O}^{17} \mathrm{O}$ ), only $\delta^{18} \mathrm{O}$ can be determined via these methods. More recently, Bao and Thiemens [54] developed a laser fluorination method, in order to precisely and simultaneously measure ${ }^{18} \mathrm{O} /{ }^{16} \mathrm{O}$ and ${ }^{17} \mathrm{O} /{ }^{16} \mathrm{O}$ from $\mathrm{O}_{2}$ extracted from sulfate samples. It is noteworthy that this method typically requires $>20-30 \mu \mathrm{mol}$ of sulfate $\left(>4-7 \mathrm{mg}\right.$ of $\mathrm{BaSO}_{4}$ ), so that enough material remains available for duplicate or triplicate analyses. Using a $\mathrm{CO}_{2}$ laser, 2-3 mg of $\mathrm{BaSO}_{4}$ reacted with $\mathrm{BrF}_{5}$ at a high temperature, leading to $\mathrm{O}_{2}$ being released, which is then extracted and purified by successive cryogenic traps in an extraction line. Finally, it is trapped onto a molecular sieve and then sent to the mass spectrometer. However, $\mathrm{O}_{2}$ extraction from $\mathrm{BaSO}_{4}$ by fluorination is never total (only $30-45 \%$ yield) [33,54], which induces an isotopic fractionation. Typical fractionation of $\delta^{18} \mathrm{O}$ is of about $+8 \%$, yet this fractionation is mass dependent, such that it has no effect on the $\Delta \Delta^{17} \mathrm{O}$ value. Overall, the method uncertainties (sulfate transformation into $\mathrm{BaSO}_{4}+\mathrm{O}_{2}$ extraction line + mass spectrometer) are: $\delta^{18} \mathrm{O} \pm 0.5 \%$ and $\Delta^{17} \mathrm{O} \pm 0.1 \% 0(2 \sigma)$.

Whilst the laser fluorination method requires a minimum of 8-10 $\mu \mathrm{mol}$ of sulfate for an O-isotopes analysis, samples as small as $0.2 \mu \mathrm{mol}$ of sulfate can be analyzed by pyrohydrolysis of $\mathrm{Ag}_{2} \mathrm{SO}_{4}$ using an elemental analyzer $[55,56]$. This method is ideally adapted for analyzing small quantities of sulfate aerosols. However, the uncertainties $\left(\delta^{18} \mathrm{O} \pm 2 \%\right.$ and $\left.\Delta^{17} \mathrm{O} \pm 0.2-0.3 \% \circ(2 \sigma)\right)$ are greater than with the laser fluorination method.

\subsection{Sulfur Isotope Measurements}

While ${ }^{34} \mathrm{~S} /{ }^{32} \mathrm{~S}$ in sulfates can be easily and directly analyzed using an elemental analyzer, multi S-isotope measurements $\left({ }^{34} \mathrm{~S} /{ }^{32} \mathrm{~S},{ }^{33} \mathrm{~S} /{ }^{32} \mathrm{~S}\right.$ and $\left.{ }^{36} \mathrm{~S} /{ }^{32} \mathrm{~S}\right)$ require that $\mathrm{Ag}_{2} \mathrm{~S}$ precipitate is converted into $\mathrm{SF}_{6}$ [51]. $\mathrm{SF}_{6}$ is obtained by fluorination (via $\mathrm{F}_{2}$ ) of $\mathrm{Ag}_{2} \mathrm{~S}$; it is then purified by gas phase chromatography, and subsequently concentrated in a cryogenic trap before being injected into the mass spectrometer. Recently, Au Yang et al. [57] developed a method allowing the analysis of less than 
$0.1 \mu \mathrm{mol}$ of $\mathrm{SF}_{6}$. Overall, the method uncertainties (sulfate transformation into $\mathrm{Ag}_{2} \mathrm{~S}+\mathrm{SF}_{6}$ extraction

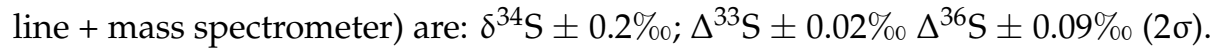

\section{Volcanic Sulfate Formation}

Sulfate aerosols can possibly be generated at high temperature in the magma itself in very oxidizing conditions or more likely in the volcanic conduit during the gas ascent. Indeed, as discussed above, they mostly consist of K-Na-sulfates and can result from the reaction between sulfuric acid and volatilized alkali-chlorides, from the condensation of alkali-sulfate directly volatilized out of the magma or emitted by the hydrothermal systems [40-43]. These sulfates are referred to as primary sulfates. Their proportion in volcanic plumes during passive magma degassing is usually low with a sulfate $/ \mathrm{SO}_{2}$ ratio, usually $<1 \%$ near the volcanic vents $[25,58,59]$. The S-bearing gases that are carried by the colder (dense or diluted) volcanic plumes and clouds produce secondary sulfate aerosols via different possible oxidation pathways in the atmosphere [20] and also possibly by chemical and photochemical reactions on mineral and dust surfaces [60]. As discussed above, these secondary sulfates consist most likely of Ca-sulfates due to interaction between sulfuric acid and volcanic glass. Below is detailed the possible mechanisms responsible for the formation of primary volcanic sulfates at high temperatures and the secondary volcanic sulfates in the troposphere, stratosphere, or during super-volcanic events.

\subsection{Isotopic Composition of S-Bearing Gases}

Due to obvious difficulties regarding a quantitative sampling close to volcanic vents, the previous determination of isotopic composition of volcanic S-bearing gases collected close to open degassing vents were only achieved at volcanic systems, where only minor eruptions occur [25-27,29,61-68]. In such open degassing systems, it appears that the $\delta^{34} \mathrm{~S}$ of the bulk volcanic S-bearing gases (mainly $\mathrm{SO}_{2}+\mathrm{H}_{2} \mathrm{~S}$ ) are rather similar to their magmatic sources, as expected since sulfur is almost thoroughly degassed (>90\%) from degassing magmas [25]. However, Menyailov et al. [26] were able to measure lower $\delta^{34} \mathrm{~S}$ for $\mathrm{H}_{2} \mathrm{~S}$ than for $\mathrm{SO}_{2}$ by $\sim 4 \%$ at $700-800{ }^{\circ} \mathrm{C}, \sim 12 \%$ at $500{ }^{\circ} \mathrm{C}$ and $\geq 16 \%$ at temperature $\leq 100{ }^{\circ} \mathrm{C}$, which is consistent with the tendency previously observed [66] and the isotopic fractionation expected between the two S-bearing gases [69,70]. While the bulk S-bearing gas has a similar composition to its magmatic source, the latter strongly depends on the oxygen fugacity of the magma, with light isotopic ratios for low oxygen fugacity (MORB-like magmas: $\delta^{34} \mathrm{~S} \sim-1 \%$ to $0 \%$; e.g., [71]) and heavier ratios when the magmatic conditions are more oxidizing (arc lavas: $\delta^{34} \mathrm{~S} \sim 5 \%$; e.g., [72]). In Figure 2, the range of -1 to $6 \%$ is reported as representative of the bulk volcanic S-bearing gases. No measures of multi-S and -O isotopes ratios have been done on the S-bearing gases. However, as it has been observed for ${ }^{34} \mathrm{~S}$, the $\Delta^{33} \mathrm{~S}, \Delta^{36} \mathrm{~S}, \delta^{18} \mathrm{O}$, and $\Delta^{17} \mathrm{O}$ of S-bearing gases is expected to be similar to the magmatic sources and the mantle values that are close to $0 \% 0$ for $\Delta^{33} \mathrm{~S}, \Delta^{36} \mathrm{~S}$, and $\Delta^{17} \mathrm{O}$ and 5.5 to $7 \%$ for $\delta^{18} \mathrm{O}$ depending on the geodynamic context ([17,71-74]; Figure 2).
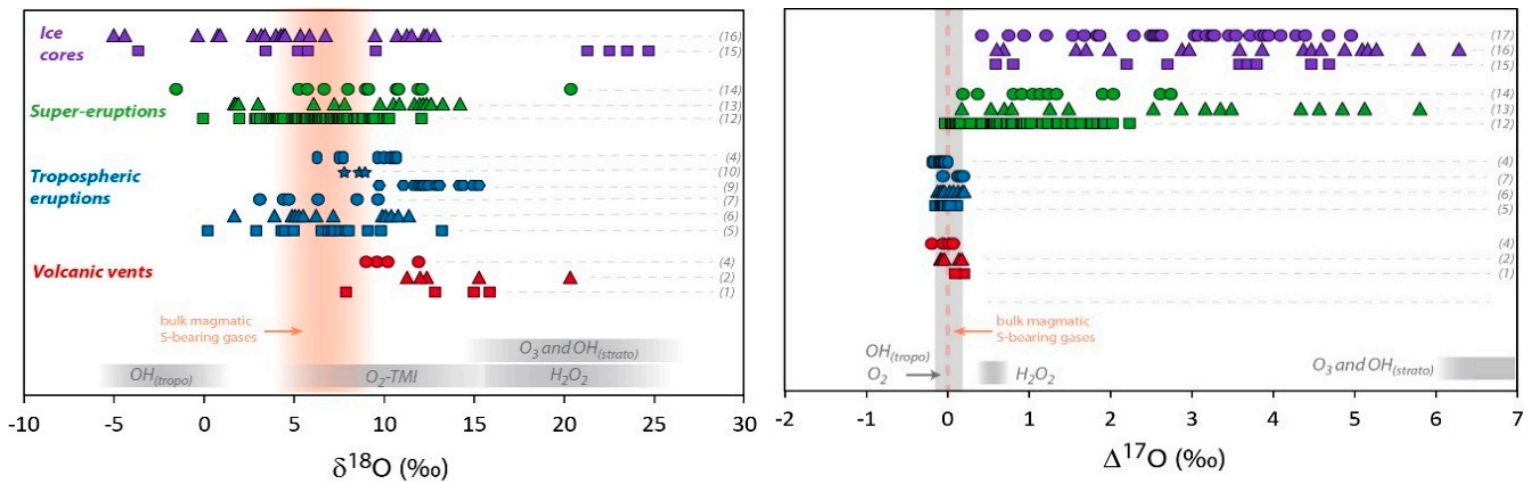

Figure 2. Cont. 

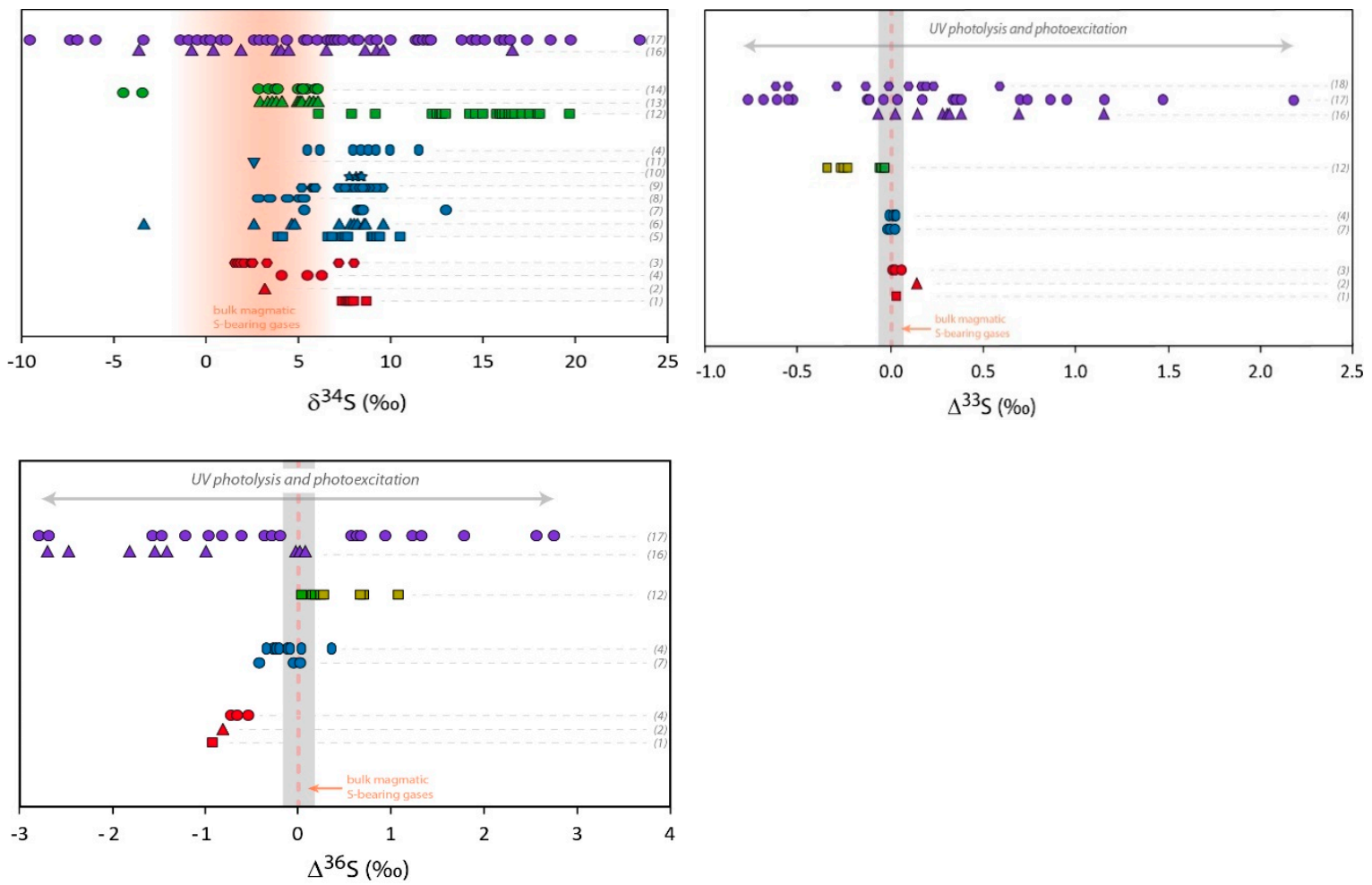

Figure 2. Multi O- and S-isotopic composition measured in volcanic sulfates. Red symbols represent primary sulfate samples collected at volcanic vents (aerosols or sulfate extracted from ashes). Blue symbols are sulfate samples extracted from volcanic deposits from tropospheric eruptions gathered at distances up to $100 \mathrm{~km}$ from the vent. Green symbols represent volcanic sulfates collected in deposits of super-eruptions at distances between $500 \mathrm{~km}$ and $5000 \mathrm{~km}$ from the volcanic systems. Pale green symbols correspond to $\Delta^{33} S$ and $\Delta^{36} S$ recalculated from the values represented by the dark green symbols, assuming dilution by non-volcanic sulfates [33]. Purple symbols represent sulfate samples from Antarctica ice cores. Mass dependent (non-MIF) compositions are emphasized by grey areas (taking into account the analytical uncertainties in $2 \sigma$ ) and bulk magmatic S-bearing gases composition by orange areas or dotted lines (see the Section 3.1 isotopic composition of S-bearing gases for further discussion). The theoretical $\delta^{18} \mathrm{O}$ and $\Delta^{17} \mathrm{O}$ composition of secondary sulfate generated in the atmosphere by different oxidation pathways are reported in grey areas. The different oxidation pathways via $\mathrm{OH}, \mathrm{H}_{2} \mathrm{O}_{2}, \mathrm{O}_{3}$, and $\mathrm{O}_{2}$-TMI are detailed in the introduction of this paper and in Figure 1 . The effect of UV photolysis and photoexcitation of $\mathrm{SO}_{2}$ on the sulfate $\Delta^{33} \mathrm{~S}$ and $\Delta^{36} \mathrm{~S}$ are shown by grey arrows. References of the figure: sulfate aerosols (1): [31]; (2): [30]; (3): [25] and references therein; sulfate extracted from volcanic ash (4): [30]; (5): [20]; (6): [35]; (7): [75]; (8): [76]; (9): [32]; (10): [77]; (11): [34]; (12): [33]; (13): [35]; (14): Unpublished data; (15): [78]; (16): [79-81]; (17): [82]. For the (16) and (17) dataset and due to significant background corrections, only samples with high volcanic fraction $(>65 \%)$ are considered here (see [82] for further discussion); (18): [83]. Note that for stratospheric aerosols collected in ice cores, even if only high volcanic fraction samples are considered, the uncertainties are typically of about: $\Delta^{17} \mathrm{O} \pm 0.5 \%, \Delta^{33} \mathrm{~S} \pm 0.1 \%$ and $\Delta^{36} \mathrm{~S} \pm 0.8 \%$ (in $2 \sigma$; see Figure 3 ).

\subsection{High Temperature Primary Sulfates}

In order to study the primary volcanic sulfates, the sampling of aerosols must be performed as close as possible to the volcanic vents (up to a few hundred meters). Figure 2 shows a compilation of the isotopic composition of such primary sulfates. The variation range for O-isotopes is from $7 \% 0$ to $20 \%$ in $\delta^{18} \mathrm{O}$ and it becomes very narrow for $\Delta^{17} \mathrm{O}$ whose values are close to $0 \%$ (from -0.18 to $+0.2 \% 0$ ). S-isotopes are more homogeneous with only $8 \%$ variation in $\delta^{34} S$ (from 1 to $9 \%$ ), $\Delta^{33} S$ 
very close to $0 \%$ or slightly positive (from 0.01 to $0.14 \%$ ) and $\Delta^{36} \mathrm{~S}$ significantly negative values from -0.5 to $-0.9 \%$.

Overall, the aerosols $\delta^{34} S$ tend to be higher than the bulk S-bearing gases, and when measured simultaneously the $\delta^{34}$ S of bulk S-bearing gases is systematically a few permil lower than in sulfate [26], in agreement with the expected isotopic fractionation [84]. The $\Delta^{33} \mathrm{~S}$ of $\sim 0 \%$ is consistent with a direct oxidation of S-bearing gases at high temperature where, like in magmatic conditions, a mass dependent isotopic fractionation is expected (e.g., [85]). In contrast, the negative $\Delta^{36} S$ values are consistent with non-MIF processes as small non-zero $\Delta^{33} \mathrm{~S}$ (between 0 and $0.14 \%$; Figure 2) and $\Delta^{36} \mathrm{~S}$ (between -0.5 and -0.9 ; Figure 2) can be generated by mass dependent processes. The observed $\Delta^{33} S / \Delta^{36} S$ ratio of about -8 is indeed in the same range as the mass dependent fractionation line that has a $\Delta^{33} S / \Delta^{36} S$ ratio between -5 and $-10[51,86,87]$ (Figure 3 ).

The measured $\delta^{18} \mathrm{O}$ values are systematically above the magmatic composition, which can be interpreted in terms of isotopic fractionation during distillation/condensation processes in the volcanic conduit and/or to sulfur oxidants that have systematically higher $\delta^{18} \mathrm{O}$ than the magma. Such oxidants could be atmospheric oxidants like $\mathrm{O}_{2}$ or $\mathrm{H}_{2} \mathrm{O}_{2}$, which could be responsible for these high $\delta^{18} \mathrm{O}$ as they can have $\delta^{18} \mathrm{O}$ higher than $20 \%$ (e.g., [20] and references therein; Figure 2). However, it is noteworthy that when sulfate aerosols are collected on filters, their $\delta^{18} \mathrm{O}$ seems to increase with the sulfate concentration $[30,31]$. This seems to show that some isotopic fractionation may occur on the filter during the sampling. In locations where such measurements have been done (Stromboli), LeGendre [30] also analyzed sulfate collected on volcanic ash and the $\delta^{18} \mathrm{O}$ is much more reproducible and corresponds to the lowest range of what was measured on filters (around $10 \%$; Figure 2). These values are closer than the magmatic values, but still slightly higher (Figure 2); therefore, we cannot rule out that atmospheric oxidants play a significant role in the high temperature chemistry at volcanic vents and therefore on the primary volcanic sulfate formation.

The $\Delta^{17} \mathrm{O}$ values are all very close to zero, indicating that the S-bearing gases oxidant is mass dependent, which is consistent with magmatic conditions, where all the compounds (volcanic gases, silicates minerals and glass) are mass dependent. If, as suggested above, some atmospheric oxidants play a significant role in the formation of the primary sulfate, these oxidants should have a $\Delta^{17} \mathrm{O}$ close to $0 \%$, which is only consistent with $\mathrm{O}_{2}\left(\Delta^{17} \mathrm{O}=-0.33 \%\right.$ ) and not $\mathrm{H}_{2} \mathrm{O}_{2}$. Indeed, even if $\Delta^{17} \mathrm{O}$ of atmospheric $\mathrm{O}_{2}$ is significantly negative, when combined with magmatic oxygen atoms in the resulting sulfate, the overall $\Delta^{17} \mathrm{O}$ should be very close to $0 \pm 0.1 \%$ (Figure 1). Overall, we could expect sulfate $\delta^{18} \mathrm{O}$ to be magmatic-like or slightly higher if atmospheric $\mathrm{O}_{2}$ played a significant role and did not isotopically exchange with magmatic compounds.

It is very challenging to assess processes that occur at high temperatures, but some studies try to do that via equilibrium thermodynamic models [88-91]. They show that, considering volcanic gas mixtures with atmospheric air during the plume cooling, $\mathrm{SO}_{3}$ can be generated from S-bearing gases and subsequently form $\mathrm{H}_{2} \mathrm{SO}_{4}$ by co-condensation along with water. Combustion experiment studies also demonstrate that ash particles and their iron oxides are excellent catalyzers to the $\mathrm{SO}_{2}$ to $\mathrm{SO}_{3}$ conversion and that the resulting sulfate is isotopically mass dependent $[92,93]$. The models also predict the formation of $\mathrm{H}, \mathrm{OH}$, and $\mathrm{OH}_{2}$ radicals that are initially coming from thermal dissociation of $\mathrm{H}_{2} \mathrm{O}$, which produces $\mathrm{H}$ and $\mathrm{OH}$ radicals reacting with atmospheric $\mathrm{O}_{2}$ to generate $\mathrm{OH}$ and $\mathrm{OH}_{2}$ [88]. The incorporation of atmospheric $\mathrm{OH}$ is also possible, but probably quickly depleted in the high temperature plume as the highly concentrated $\mathrm{SO}_{2}$ oxidation (via $\mathrm{OH}$ ) would rapidly consume it.

\subsection{Tropospheric Secondary Sulfates}

Secondary sulfates are generated by oxidation of sulfur precursors in the atmosphere, either in the gas or condensed phases. When the volcanic plume does not reach the stratosphere, and remains in the troposphere, it is possible to address the formation of secondary sulfates in a more or less diluted volcanic tropospheric plume or cloud, by collecting sulfates from volcanic ashes deposited at distances even up to a few hundred kilometers from the volcanic vent [20]. Such sulfates measured all over 
the world show compositions ranging from 0 to $15 \%$ for both $\delta^{18} \mathrm{O}$ and $\delta^{34} S$; their $\Delta^{17} \mathrm{O}, \Delta^{33} \mathrm{~S}$ and $\Delta^{36} \mathrm{~S}$ values are very homogeneous and very close to $0 \%$ as well (Figure 2). In detail, $\Delta^{36} \mathrm{~S} / \Delta^{33} \mathrm{~S}$ of about -9.4 is similar to what is observed close to volcanic vents and close to the mass dependent fractionation line (Figure 3).

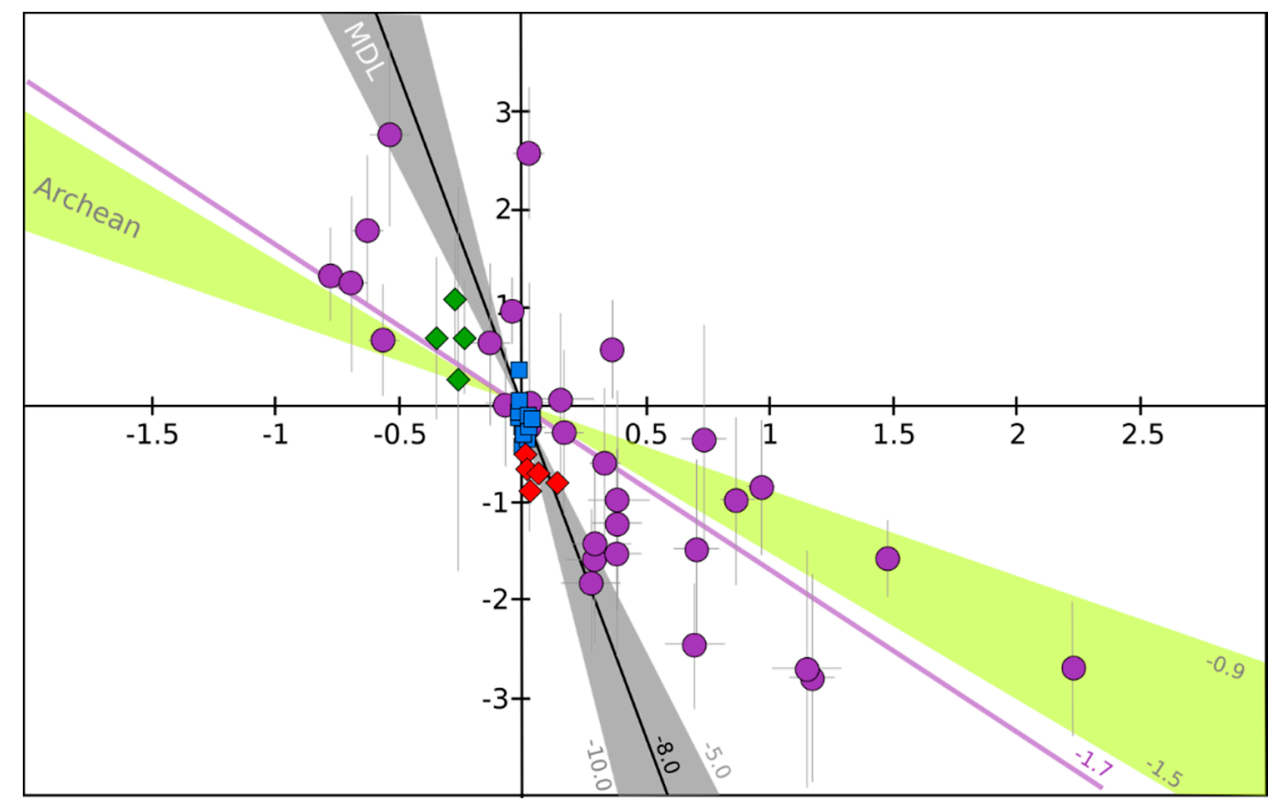

Figure 3. $\Delta^{33} \mathrm{~S}$ versus $\Delta^{36} \mathrm{~S}$ relationship for volcanic sulfates collected close the vents (in red), from volcanic deposits of tropospheric eruptions (in blue), super-eruptions (in green), and from ice cores recording stratospheric eruptions (in purple). All the dataset is the same as in the Figure 2. MDL: mass dependent fractionation line which has a slope between -10.0 and $-5.0(-6.58$ in average) and Archean (yellow zone), corresponds to reference array defined by Archean rock samples, and have a slope between -1.5 and -0.9 . For more details, the reader is invited to read the recent review on the subject by Ono [94]. Despite the analytical uncertainties, specifically on $\Delta^{36} \mathrm{~S}$ from ice core sulfates samples (see the error bars in $2 \sigma$ ), which induce possible large uncertainties on the $\Delta^{33} S / \Delta^{36} S$ ratios (lines) defined by volcanic samples, some general conclusion can still be addressed. Volcanic sulfates produced in volcanic vent at high temperatures and in the troposphere define a line with a slope of about $-8.0\left(R^{2}=0.61\right)$, which is comparable to the MDL. However, volcanic sulfate from stratospheric and super-eruptions define a line with a slope of about $-1.7\left(R^{2}=0.65\right)$, which is clearly not comparable to the MDL but very close to the Archean array.

Models of tropospheric chemistry show that $\mathrm{SO}_{2}$ must be overwhelmingly oxidized by $\mathrm{H}_{2} \mathrm{O}_{2}$ when $\mathrm{pH}<6$, which is expected to be the case in volcanic plume. However, as all non-volcanic tropospheric sulfates have a $\Delta^{17} \mathrm{O}$ of about $0.7 \%$ (e.g., references [30,92,95-97]), this should also be the case for volcanic tropospheric sulfates (Figure 1). The fact that $\Delta^{17} \mathrm{O}$ of tropospheric volcanic sulfate is close to $0 \%$, clearly shows that $\mathrm{H}_{2} \mathrm{O}_{2}$ is not the main oxidant. Based on the fact that $\mathrm{H}_{2} \mathrm{O}_{2}$ concentration in the troposphere $\left(\mathrm{H}_{2} \mathrm{O}_{2}\right.$ concentration $=\left[\mathrm{H}_{2} \mathrm{O}_{2}\right]<0.5$ DU; Dobson unit; $1 \mathrm{DU}=2.68 \times 10^{16}$ molecule $\mathrm{cm}^{-2}$ ) is much lower than the concentration of volcanic $\mathrm{SO}_{2}$ in the volcanic plumes ([SO $\left.\mathrm{SO}_{2}\right]=10-100 \mathrm{DU}$; e.g., [98,99]), Martin et al. [20] proposed that $\mathrm{H}_{2} \mathrm{O}_{2}$ reacts and is rapidly consumed in the tropospheric column. The second main oxidants are $\mathrm{OH}(\mathrm{Ch} 1)$ or $\mathrm{O}_{2}(\mathrm{Ch} 4)$ that are non-MIF (or slightly negative for $\mathrm{O}_{2}$ ). Consequently, they logically produce sulfate aerosols with $\Delta{ }^{17} \mathrm{O}$ very close to $0 \%$ (Figure 1 ). In tropospheric volcanic plumes, when tropospheric humidity is high (water condensation in the plume), heterogeneous aqueous oxidation reaction via $\mathrm{O}_{2}$-TMI is expected to be faster than homogeneous gas phase reaction via $\mathrm{OH}$. However, in relatively low humidity conditions (no condensing plume), the oxidation via $\mathrm{OH}$ should dominate [100]. This is in 
agreement with observations made at Kilauea (Hawaii) where diurnal variations in the sulfate fraction $\left(\left[\mathrm{SO}_{4}^{2-}\right] /\left(\left[\mathrm{SO}_{4}^{2-}\right]+\left[\mathrm{SO}_{2}\right]\right)\right)$ have been observed in the volcanic plume, indicating that photochemically produced oxidants play a major role in the $\mathrm{SO}_{2}$ oxidation [101]. $\mathrm{OH}$ and $\mathrm{H}_{2} \mathrm{O}_{2}$ are photochemically produced oxidants but, as discussed above, oxidation via $\mathrm{H}_{2} \mathrm{O}_{2}$ cannot explain the non-MIF isotopic composition of volcanic sulfate produced in the troposphere. Therefore, oxidation via $\mathrm{OH}$ seems to play the main role in relatively dry condition plumes.

Finally, collecting tropospheric secondary sulfates from volcanic ashes could be biased by the fact that primary sulfates adsorbed on ash particles are still present, which dilutes the secondary sulfate isotopic signature. Unfortunately, based only on petrographic observations and on O-isotopic signatures of these sulfates, distinguishing a primary vs. secondary origin (Figure 2) is a strenuous task. However, as measured at volcanic vents, the sulfate $/ \mathrm{SO}_{2}$ ratio is usually $<1 \%[25,58,59]$, indicating that further away from the vent, after oxidation of some $\mathrm{SO}_{2}$ in the volcanic plume, secondary sulfate should rapidly (in a few hours) dominate the primary ones. Therefore, in ash deposit collected at more than $\sim 30-50 \mathrm{~km}$ from the volcanic vent, secondary sulfate should dominate. However, secondary sulfate could also be generated in volcanic plumes by other processes such as S-bearing gases oxidation by $\mathrm{OH}$ radicals produced on ash particles (e.g., [60,102-105]). Additionally, another way of producing secondary sulfate in the volcanic plume can be the $\mathrm{SO}_{2}$ reaction with halogen species ( $\mathrm{HOBr}$ or $\mathrm{HOCl}$ ) dissolved in the aqueous phase [106,107]. Unfortunately, yet very little is known on the conditions prevailing inside the dense and hot volcanic plumes. For instance, in such an environment, the halogen chemical behaviors are poorly constrained so it is difficult to estimate the role played in volcanic plumes by these oxidation channels.

In a tropospheric volcanic plume, the estimation of the conversion of $\mathrm{SO}_{2}$ into sulfate aerosols is a key parameter in order to have accurate volcanic S-spices fluxes, which is crucial in volcano monitoring (see [5] for a review). The $\mathrm{SO}_{2}$ oxidation rate depends on the oxidation pathways, which as discussed above, depend on the $\mathrm{SO}_{2}$ concentration, the relative humidity, the time of the day and the season of the year. In tropospheric volcanic plumes, the estimations of $\mathrm{SO}_{2}$ oxidation rates usually range from $\sim 10^{-7} \mathrm{~s}^{-1}$ to $\sim 10^{-4} \mathrm{~s}^{-1}$ ([101] and references therein). It is noteworthy that these estimations can be biased by the content of primary sulfate, loss of $\mathrm{SO}_{2}$ by non-oxidative processes, and the presence of aerosols other than sulfates. These parameters are not easy to quantify and are often not taken into account, leading to large uncertainties on the $\mathrm{SO}_{2}$ oxidation rate. Kroll et al. [101] measured in real-time the $\mathrm{SO}_{2}$ and sulfate concentrations in the Kilauea volcanic plume and inferred $\mathrm{SO}_{2}$ oxidation rates up to $2.5 \times 10^{-6} \mathrm{~s}^{-1}$ at noon and an average over $24 \mathrm{~h}$ of $5.3 \times 10^{-7} \mathrm{~s}^{-1}$, which is in the lower range of all the previous estimations. Values of about $10^{-7} \mathrm{~s}^{-1}$ are also inferred from atmospheric chemistry models that do not include halogen chemistry, which is comparable to the Kilauea case, where halogen emissions are rather low (Galeazzo, personal communication).

\subsection{Stratospheric Secondary Sulfates}

During major explosive volcanic eruptions, the volcanic plume can reach the stratosphere. There, S-bearing gases can be oxidized and form sulfate aerosols that, due to strong stratospheric winds, are able to travel long distances, to be potentially dispersed globally and finally to slowly sediment on the Earth's surface. It is striking that, due to atmospheric circulation, a volcanic plume emitted in the tropics is easily spread out all over the globe, while at a higher latitude it remains in the same hemisphere. Furthermore, and for the same reasons, the concentration of volcanic sulfate aerosols is unlikely to be homogeneous on the deposition area.

This has been very well demonstrated for the 1991 Pinatubo eruption (e.g., [108]). These stratospheric volcanic sulfate aerosols can be ideally sampled in polar ice cores. Indeed, for the last hundred thousand years, ice accumulation at the poles has progressively recorded and archived atmosphere compositions. Thanks to its chemical stability (very low volatility and reactivity with other compounds), and taking into account some snow redistribution by the wind, the sulfate concentration in the ice has been used for decades to identify volcanic events (references [109-113] among others). 
In Antarctica, O- and S-isotope compositions of these sulfates have been studied [78-81]. It is noteworthy that background correction is necessary as concentration up to $100 \mathrm{ppb}$ of mostly biogenic sulfate can be present. There, $\delta^{18} \mathrm{O}$ ranges from $-5 \%$ to $+25 \%$, and $\delta^{34} \mathrm{~S}$ : from $-5 \%$ to $+20 \%$ o (Figure 2). Furthermore, S- and O-MIF signatures $\left(-0.8 \% 0<\Delta^{33} \mathrm{~S}<2.2 \% ;-2.7 \%_{0}<\Delta^{36} \mathrm{~S}<2.8 \%_{0}\right.$ and $\Delta^{17} \mathrm{O}$ up 6.5\%; Figure 2) were recorded in the sulfates from more than ten stratospheric eruptions (e.g., Pinatubo, Agung, Krakatoa, Kuwae and different unknown eruptions). Note that the average $\Delta^{33} \mathrm{~S} / \Delta^{36} \mathrm{~S}$ ratio from this dataset is about -1.7 , which is clearly different from the mass dependent fractionation line ratio ( -5 to -10 ; see [94] for a review; Figure 3).

The most accepted process for generating such S-MIF signatures consists of the photolysis and photoexcitation of $\mathrm{SO}_{2}$ by UV radiations, in an oxygen-poor atmosphere ([12,21,22,114-116] and [94] for a review). On the early Earth, before the great oxidation event (2.4-2.2 Ga), there was no atmospheric oxygen and consequently, no ozone layer. So, due to the lack of this shield, UV radiation reached the surface of the Earth, such that sulfur photolysis and photoexcitation could take place through the whole atmospheric column, resulting in possibly large S-MIF. Since then, the ozone layer has partially protected the Earth's surface from UV radiation. Consequently, the only place where such processes can take place (and generate large S-MIF signatures) is in the stratosphere above or in the upper part of the ozone layer $(\geq 25 \mathrm{~km})$. Volcanic sulfate aerosols generated in the stratosphere are thus expected to have S-MIF signatures [114,117]. Therefore, volcanic sulfate aerosols having large S-MIF signatures clearly testify to their stratospheric origin.

In ice-cores, an evolution of $\Delta^{33} S$ from negative to positive and $\Delta^{36} S$ from positive to negative is recorded during a single volcanic event $[80,82]$. This can be explained by formation in the stratosphere of ${ }^{33} \mathrm{~S}$ enriched and ${ }^{36} \mathrm{~S}$ depleted sulfate aerosols at first and then, by mass balance, the resulting $\mathrm{SO}_{2}$ pool generates sulfates that are ${ }^{33} \mathrm{~S}$ depleted and ${ }^{36} \mathrm{~S}$ enriched [82]. However, in the stratosphere, the S-bearing gases oxidation after an eruption takes a few months, while the ice volcanic sulfate records are on a timescale of years. This requires a physical separation in space and time of the $\mathrm{SO}_{2}$ and generated sulfates right from the beginning of the $\mathrm{SO}_{2}$ oxidation in the stratosphere and maintained separated for a few years while traveling in the stratosphere and while depositing in formation-time order in the ice.

The large O-MIF signature ( $\Delta^{17} \mathrm{O}$ up to $6.5 \%$ ) observed in the same stratospheric sulfates $[78,79]$ can only be explained by the oxidation of S-bearing gases by $\mathrm{OH}$ radicals that have high $\Delta^{17} \mathrm{O}$. Indeed, as $\mathrm{OH}$ results from $\mathrm{O}_{3}$ photo-dissociation, they carry the same isotopic anomaly as $\mathrm{O}_{3}$ (Figure 1 ). Due to isotopic exchange with non-MIF water, tropospheric $\mathrm{OH}$ is $\mathrm{O}$-mass dependent $\left(\Delta^{17} \mathrm{O}=0 \%\right.$; Figure 1). The "cold trap" effect played by the tropopause prevents significant water transfers between troposphere and stratosphere. This lack of exchanges results in the low water content in the stratosphere (2-6 ppmv which is 3-4 orders of magnitude lower than in the troposphere) [118]. These relatively anhydrous stratospheric conditions favor homogeneous (gas phase) oxidation of $\mathrm{SO}_{2}$; in that case, the main oxidant of volcanic sulfur is $\mathrm{OH}$ (Figure 1). It is noteworthy that during major eruptions, the water-rich volcanic plumes reach the stratosphere where they could provide significant amounts of water (at least locally), such that heterogeneous gas phase oxidation by $\mathrm{O}_{3}$ could potentially play a significant role as well. Unfortunately, taken alone, O-isotopes do not allow precise quantification of the relative role played by $\mathrm{O}_{3}$ or $\mathrm{OH}$ in the stratospheric oxidation of sulfur. If the ozone plays a role in such diluted stratospheric volcanic plumes, it means that the conditions are rather basic and not acidic as in denser plumes. In the case where acidic conditions are still preserved, then the $\mathrm{SO}_{2}$ oxidation via $\mathrm{O}_{2}$-TMI should prevail, which should lead to a decrease of the sulfate $\Delta^{17} \mathrm{O}$. This could explain the fact that some sulfates generated during large eruptions and collected in ice-core do not have high $\Delta^{17} \mathrm{O}$ signatures [78]. However, these low values seem to correlate with very large eruptions that inject more than $100 \mathrm{Mt}$ of $\mathrm{SO}_{2}$ into the stratosphere. Savarino et al. [78] proposed that in such conditions, $\mathrm{OH}$ radicals could be rapidly exhausted and that oxidation via $\mathrm{O}\left({ }^{3} \mathrm{P}\right)$, which quickly reacts with $\mathrm{O}_{2}$ that has a $\Delta^{17} \mathrm{O}$ very close to $0 \%$, could be the main mechanism taking place in the stratosphere during these exceptional volcanic eruptions. 


\subsection{Ash Layer from Large Caldera-Forming Eruptions (Super-Eruptions)}

Super-eruptions correspond to volcanic eruptions that emit more than $1000 \mathrm{~km}^{3}$ of fragmental material (mainly ash) and form large calderas. Sulfates extracted from these deposits display a wide range of isotopic compositions: $\delta^{18} \mathrm{O}$ and $\delta^{34} \mathrm{~S}$ generally spread from $0 \%$ to $15 \%, \Delta^{17} \mathrm{O}$ from $0 \%$ up to $6 \%$, while $\Delta^{33} \mathrm{~S}$ and $\Delta^{36} \mathrm{~S}$ remain very close to $0 \%$ (Figure 2). The study of super-eruption deposits raises some questions that are still under debate [33,35]. During super-eruptions, such as those from Yellowstone (Lava Creek Tuff, 0.64 Ma; Huckleberry Ridge Tuff, 2.1 Ma) and the Long Valley eruption (Bishop tuff, $0.76 \mathrm{Ma}$ ), ashes have been deposited at distances up to $5000 \mathrm{~km}$ from their source calderas. As discussed above, at such distances, the fraction of primary sulfates should be negligible compared to secondary sulfates. Even if these old ash layers (hundreds of ka to tens of Ma), have been diluted by non-MIF sedimentary sulfates, O- and S-MIF signatures could still have been preserved. Indeed, Martin and Bindeman [33] have shown that up to $25 \%$ of O- and S-MIF volcanic sulfates are still preserved in some Yellowstone and Bishop Tuff volcanic deposits. Taking into account the effects of dilution, the authors were able to recalculate the $\Delta^{33} S$ and $\Delta^{36} S$ of the initial volcanic sulfates, which have an unambiguous S-MIF signature $\left(\Delta^{33} S\right.$ down to $-0.4 \%$ and $\Delta^{36}$ S up to $1.2 \%$; Figure 2). Therefore, even in deposits located within a radius of a few thousands of kilometers from the caldera, S-MIF sulfates are observed, which indicates that a significant amount of stratospheric sulfates is still present in super-eruption deposits. It is noteworthy that Bao et al. [119] proposed that the sulfate O-MIF signature from super-eruption deposits could be accounted by tropospheric oxidation via $\mathrm{O}_{3}$. This is possible in basic environments $(\mathrm{pH}>6)$, however it is inconsistent with the acidic (low $\mathrm{pH}$ ) character of dense volcanic plumes. Nonetheless, such conclusions raise new questions.

(A) The tropospheric origin of sulfates: If the O-MIF (up to 6\%) sulfates are generated in the troposphere, $\mathrm{O}_{3}$ must have played an important role (Figure 1), which seems unlikely considering acidic conditions of volcanic plumes. Furthermore, if S-MIF is also generated in the troposphere during super-eruptions, it has to be considered that the ozone layer was depleted, at least locally, such that a significant fraction of UV radiation was able to reach the troposphere, thus making $\mathrm{SO}_{2}$ photoexcitation and photolysis possible. It is noteworthy that such a process is compatible with the UV-B flux variations possibly linked to the large igneous provinces emplacements $([120,121]$ and reference therein).

(B) The stratospheric origin of sulfates: If sulfates are generated by $\mathrm{O}_{3}$ (aqueous phase oxidation) in the stratosphere, does it get at least locally hydrated? Such a scenario was observed after the $1982 \mathrm{El}$ Chichon eruption [122,123], but the injection of $\mathrm{SO}_{2}$ in the stratosphere could also lead to the drying out of the stratosphere [124] which makes it difficult to give a general answer to this question. Indeed, the formation of sulfates in the stratosphere by $\mathrm{OH}$ oxidation would account for both O- and S-MIF signatures. In turn, this scenario implies that the watering of the stratosphere must be negligible, otherwise $\mathrm{OH}$ should react with $\mathrm{H}_{2} \mathrm{O}$ and dilute its positive $\Delta \Delta^{17} \mathrm{O}$ signature. It must be noted that in very high $\mathrm{SO}_{2}$ concentration conditions, $\mathrm{OH}$ can react significantly with $\mathrm{SO}_{2}$ before isotopic exchange with water (Galeazzo, personal communication). The fact that all the $\Delta^{17} \mathrm{O}$ measured is lower than $8.8 \%$, as expected by $\mathrm{OH}$ oxidation (Figure 1), can obviously be explained by non-MIF sediment sulfate dilution in the volcanic deposit, but it could also be explained by another oxidation pathway in the stratosphere. For large stratospheric eruptions, it has been suggested that, due to $\mathrm{OH}$ depletion, oxidation via $\mathrm{O}\left({ }^{3} \mathrm{P}\right)$ could generate non-MIF sulfate [78]. In any case, the stratospheric origin is unable to explain why such an amount of sulfate (up to a few hundreds of ppm) can be found in an area of a few hundreds to thousands of kilometers around the caldera while it should have been spread out all around the world (or at least hemispherically for high latitude eruptions) as it is observed for stratospheric eruptions.

(C) The mixed origin of sulfates: This raises questions about the physico-chemical properties of the tropopause during such volcanic events. After the 1982 El Chichon and the 1991 Pinatubo eruptions for instance the temperature of the low stratosphere increased up to $1.5^{\circ} \mathrm{C}$ [9]. If a significant temperature increase had occurred at the tropopause, its "cold trap" effect would have been partially reduced, 
thus facilitating chemical fluxes $\left(\mathrm{O}_{3}\right.$ and $\mathrm{H}_{2} \mathrm{O}$ for instance) between the troposphere and stratosphere. Even if the impact was global, the apogee of such an effect could have been restricted to a few hundreds to thousands of kilometers in the atmospheric column located above the volcanic systems.

\section{Summary and Conclusions}

Oxygen and sulfur isotopes provide good constraints on the formation and fate of volcanic sulfate aerosols and ultimately the real nature of the physico-chemical interactions between the atmosphere and volcanic eruptions. Multi O- and S-isotope analyses of sulfates collected by air sampling or volcanic ash leaching allow us to decipher the oxidation pathways of S-bearing gases in the atmosphere. They also discriminate between primary vs. secondary aerosols and give information about the place where they were generated (troposphere vs. stratosphere).

Some aspects need to be improved:

- $\quad$ High temperature chemistry (including sulfate aerosol formation) is assessed by equilibrium thermodynamic models, but at volcanic vents the plume cools down and dilutes very quickly, therefore modeling using a kinetic approach should be more appropriate.

- $\quad$ The isotopic approach alone can hardly differentiate between different possible mass-dependent processes responsible for sulfate formation. In volcanic plumes, sulfates can be generated by oxidation channels such as $\mathrm{OH}$ or $\mathrm{O}_{2}$-TMI oxidation, but the exploration of other possible oxidation processes is required. The role played by halogens and $\mathrm{OH}$ radicals generated from ash particles in the $\mathrm{SO}_{2}$ oxidation needs to be quantified as in volcanic plumes they may play a more preponderant role than expected. This would improve our understanding of sulfate aerosol formation in a relatively particle-dense plume or cloud.

- $\quad$ In the stratosphere, the low $\Delta^{17} \mathrm{O}$ sulfates are not totally understood yet. Oxidation channels other than oxidation via $\mathrm{OH}$ need to be explored. Furthermore, the fact that in ice-cores the evolution of $\Delta^{33} S$ (from negative to positive) and $\Delta^{36} S$ (from positive to negative) is recorded during a single volcanic event on a year timescale, while the $\mathrm{SO}_{2}$ oxidation in the stratosphere takes a few months after an eruption, is still unexplained.

- The impact of super-eruptions on the atmosphere and more specifically on the tropopause needs to be explored in more detail in order to better constrain the potential chemical fluxes between the troposphere and the stratosphere during such an event. This would have an impact on the sulfate aerosol formation and on the atmospheric and climatic impact of super-eruptions in general.

In dry environments, sulfates can be preserved in volcanic deposits for millions of years, thus they can be considered as a reliable archive having recorded the impact on the atmosphere of ancient volcanic eruptions. Furthermore, volcanoes are widespread all over the world, and they have erupted more or less regularly over the Earth's history. Consequently, volcanic sulfates can also be used as proper proxies for the oxidant capacity of the atmosphere on a geological timescale. This would represent an additional constraint on the climatic models for the past but also the future periods of times. From this point of view, the study of volcanic sulfates could provide an open window on past and future climatic changes. Additionally, a better understanding of sulfate aerosol formation and fate in the atmosphere would provide a new parameter in our understanding of atmospheric chemistry evolution. A similar approach performed on anthropogenic S-bearing emissions would significantly improve our knowledge on present-day atmospheric chemistry. This appears to be a fundamental parameter for climatic modeling and for a better prediction of forthcoming climatic changes.

Acknowledgments: The author expresses his sincere thanks the "Emergence program" from the city of Paris, the Agence National de la recherche (ANR) via the contracts 14-CE33-0009-02-FOFAMIFS and 16-CE31-0010-PaleOX, the Sorbonne Universités and the KIC-Climate PhD programs for their support. He is also grateful to E. LeGendre, H. Martin, S. Bekki, I. Bindeman, T. Galeazzo, A. Aroskay, E. Gautier and L. Whiteley for their informal reviews, discussions and proof-reading of the manuscript. The author thanks the anonymous reviewers for their comments that certainly improved the manuscript.

Conflicts of Interest: The author declares no conflict of interest. 


\section{References}

1. Andres, R.J.; Kasgnoc, A.D. A time-averaged inventory of subaerial volcanic sulfur emissions. J. Geophys. Res. Atmos. 1998, 103, 25251-25261. [CrossRef]

2. Graf, H.-F.; Feichter, J.; Langmann, B. Volcanic sulfur emissions: Estimates of source strength and its contribution to the global sulfate distribution. J. Geophys. Res. Atmos. 1997, 102, 10727-10738. [CrossRef]

3. Textor, C.; Graf, H.-F.; Timmreck, C.; Robock, A. Emissions from volcanoes. In Emissions of Atmospheric Trace Compounds; Advances in Global Change Research; Springer: Dordrecht, The Netherlands, 2004; pp. 269-303, ISBN 978-90-481-6605-3.

4. Delmelle, P.; Stix, J. Volcanic gases. In Encyclopedia of Volcanoes; Sigurdsson, H., Houghton, B., McNutt, S.R., Rymer, H., Stix, J., Eds.; Elsevier: New York, NY, USA, 2000; pp. 803-815.

5. Oppenheimer, C.; Scaillet, B.; Martin, R.S. Sulfur Degassing From Volcanoes: Source Conditions, Surveillance, Plume Chemistry and Earth System Impacts. Rev. Mineral. Geochem. 2011, 73, 363-421. [CrossRef]

6. Haywood, J.; Boucher, O. Estimates of the direct and indirect radiative forcing due to tropospheric aerosols: A review. Rev. Geophys. 2000, 38, 513-543. [CrossRef]

7. Robock, A. Volcanic eruption and climate. Rev. Geophys. 2000, 38, 191-219. [CrossRef]

8. Hansen, J.E.; Wang, W.-C.; Lacis, A.A. Mount Agung Eruption Provides Test of a Global Climatic Perturbation. Science 1978, 199, 1065-1068. [CrossRef] [PubMed]

9. Parker, D.E.; Wilson, H.; Jones, P.D.; Christy, J.R.; Folland, C.K. The impact of mount pinatubo on world-wide temperatures. Int. J. Climatol. 1996, 16, 487-497. [CrossRef]

10. Parker, D.E.; Brownscombe, J.L. Stratospheric warming following the El Chichón volcanic eruption. Nature 1983, 301, 406-408. [CrossRef]

11. Rampino, M.R.; Self, S. Historic Eruptions of Tambora (1815), Krakatau (1883), and Agung (1963), their Stratospheric Aerosols, and Climatic Impact. Quat. Res. 1982, 18, 127-143. [CrossRef]

12. Farquhar, J.; Savarino, J.; Airieau, S.; Thiemens, M.H. Observation of wavelength-sensitive mass-independent sulfur isotope effects during $\mathrm{SO}_{2}$ photolysis: Implications for the early atmosphere. Geophys. Res. 2001, 106, 32829-32839. [CrossRef]

13. Farquhar, J.; Bao, H.; Thiemens, M. Atmospheric Influence of Earth's Earliest Sulfur Cycle. Science 2000, 289, 756-758. [CrossRef] [PubMed]

14. Thiemens, M.H. History and applications of mass-independent isotope effects. Annu. Rev. Earth Planet. Sci. 2006, 34, 217-262. [CrossRef]

15. Thiemens, M.H.; Heidenreich, J.E. The Mass-Independent Fractionation of Oxygen: A Novel Isotope Effect and Its Possible Cosmochemical Implications. Science 1983, 219, 1073-1075. [CrossRef] [PubMed]

16. Farquhar, J.; Wing, B.A. Multiple sulfur isotopes and the evolution of the atmosphere. Earth Planet. Sci. Lett. 2003, 213, 1-13. [CrossRef]

17. Rumble, D.; Miller, M.F.; Franchi, I.A.; Greenwood, R.C. Oxygen three-isotope fractionation lines in terrestrial silicate minerals: An inter-laboratory comparison of hydrothermal quartz and eclogitic garnet. Geochim. Cosmochim. Acta 2007, 71, 3592-3600. [CrossRef]

18. Seinfeld, J.H.; Pandis, S.N. Atmospheric Chemistry and Physics: From Air Pollution to Climate Change, 2nd ed.; John Wiley \& Sons: New York, NY, USA, 2006.

19. Savarino, J.; Lee, C.C.W.; Thiemens, M.H. Laboratory oxygen isotopic study of sulfur (IV) oxidation: Origin of the mass-independent oxygen isotopic anomaly in atmospheric sulfates and sulfate mineral deposits on Earth. J. Geophys. Res. Atmos. 2000, 105, 29079-29088. [CrossRef]

20. Martin, E.; Bekki, S.; Ninin, C.; Bindeman, I. Volcanic sulfate aerosol formation in the troposphere. J. Geophys. Res. Atmos. 2014, 119, 12:660-12:673. [CrossRef]

21. Ono, S.; Whitehill, A.R.; Lyons, J.R. Contribution of isotopologue self-shielding to sulfur massindependent fractionation during sulfur dioxide photolysis. Ournal Geophys. Res. Atmos. 2013, 118, 2444-2454. [CrossRef]

22. Whitehill, A.R.; Xie, C.; Hu, X.; Xie, D.; Guo, H.; Ono, S. Vibronic origin of sulfur mass-independent isotope effect in photoexcitation of $\mathrm{SO}_{2}$ and the implications to the early earth's atmosphere. Proc. Natl. Acad. Sci. USA 2013, 110, 17697-17702. [CrossRef] [PubMed]

23. Giggenbach, W.F. A simple method for the collection and analysis of volcanic gas samples. Bull. Volcanol. 1975, 39, 132-145. [CrossRef] 
24. Giggenbach, W.F.; Goguel, R.L. Methods for the Collection and Analysis of Geothermal and Volcanic Water and Gas Samples; Chemistry Division, Department of Scientific and Industrial Research: Petone, New Zealand, $1989 ;$ p. 53.

25. De Moor, J.M.; Fischer, T.P.; Sharp, Z.D.; King, P.L.; Wilke, M.; Botcharnikov, R.E.; Cottrell, E.; Zelenski, M.; Marty, B.; Klimm, K.; et al. Sulfur degassing at Erta Ale (Ethiopia) and Masaya (Nicaragua) volcanoes: Implications for degassing processes and oxygen fugacities of basaltic systems: Sulfur Degassing at Basaltic Volcanoes. Geochem. Geophys. Geosyst. 2013, 14, 4076-4108. [CrossRef]

26. Menyailov, I.A.; Nikitina, L.P.; Shapar, V.N.; Pilipenko, V.P. Temperature increase and chemical change of fumarolic gases at Momotombo Volcano, Nicaragua, in 1982-1985: Are these indicators of a possible eruption? J. Geophys. Res. Solid Earth 1986, 91, 12199-12214. [CrossRef]

27. Goff, F.; Janik, C.J.; Delgado, H.; Werner, C.; Counce, D.; Stimac, J.A.; Siebe, C.; Love, S.P.; Williams, S.N.; Fischer, T.; et al. Geochemical surveillance of magmatic volatiles at Popocatépetl volcano, Mexico. GSA Bull. 1998, 110, 695-710. [CrossRef]

28. Ohba, T.; Nogami, K.; Hirabayashi, J.-I.; Mori, T. Isotopic fractionation of $\mathrm{SO}_{2}$ and $\mathrm{H}_{2} \mathrm{~S}$ gases during the absorption by $\mathrm{KOH}$ solution, with the application to volcanic gas monitoring at Miyakejima Island, Japan. Geochem. J. 2008, 42, 119-131. [CrossRef]

29. Mather, T.A.; Pyle, D.M.; Heaton, T.H.E. Investigation of the use of filter packs to measure the sulphur isotopic composition of volcanic sulphur dioxide and the sulphur and oxygen isotopic composition of volcanic sulphate aerosol. Atmos. Environ. 2008, 42, 4611-4618. [CrossRef]

30. Le Gendre, E. Étude des Anomalies Isotopiques de L'oxygène Etdusoufre Dans les Sulfates D'origine Volcanique et Anthropique; UPMC: Pittsburgh, PA, USA, 2016.

31. Mather, T.A.; McCabe, J.R.; Rai, V.K.; Thiemens, M.H.; Pyle, D.M.; Heaton, T.H.E.; Sloane, H.J.; Fern, G.R. Oxygen and sulfur isotopic composition of volcanic sulfate aerosol at the point of emission. J. Geophys. Res. Atmos. 2006, 111, D18205. [CrossRef]

32. Armienta, M.A.; De la Cruz-Reyna, S.; Soler, A.; Cruz, O.; Ceniceros, N.; Aguayo, A. Chemistry of ash-leachates to monitor volcanic activity: An application to Popocatépetl volcano, central Mexico. Appl. Geochem. 2010, 25, 1198-1205. [CrossRef]

33. Martin, E.; Bindeman, I. Mass-independent isotopic signatures of volcanic sulfate from three supereruption ash deposits in Lake Tecopa, California. Earth Planet. Sci. Lett. 2009, 282, 102-114. [CrossRef]

34. Risacher, F.; Alonso, H. Geochemistry of ash leachates from the 1993 Lascar eruption, northern Chile. Implication for recycling of ancient evaporites. J. Volcanol. Geotherm. Res. 2001, 109, 319-337. [CrossRef]

35. Bao, H.; Thiemens, M.H.; Loope, D.B.; Yuan, X.-L. Sulfate oxygen-17 anomaly in an Oligocene ash bed in mid-North America: Was it the dry fogs? Geophys. Res. Lett. 2003, 30, 11-14. [CrossRef]

36. Van Stempvoort, D.R.; Krouse, H.R. Controls of $\mathrm{d}^{18} \mathrm{O}$ in sulfate: Review of experimental data and application to specific environments. In Environmental Geochemistry of Sulfide Oxidation; Alpers, C.N., Blowes, D.W., Eds.; American Chemical Society: Washington, DC, USA, 1994; Volume 550.

37. Witham, C.S.; Oppenheimer, C.; Horwell, C.J. Volcanic ash-leachates: A review and recommendations for sampling methods. J. Volcanol. Geotherm. Res. 2005, 141, 299-326. [CrossRef]

38. Botter, C. Utomated Single-Particle SEM/EDS Analysis of Volcanic Aerosols from Stromboli, Aeolian Arc, Italy; Mineralogical Characterization of the PM10 Fraction; University of Fribourg: Fribourg, Switzerland, 2011.

39. Botter, C.; Meier, M.; Wiedenmann, D.; Grobety, B.; Ricci, T. Single Particle Analysis of Volcanic Aerosols from Stromboli, Italy. In Proceedings of the Cities on Volcanoes 6 (COV6), Tenerife, Spain, 31 May-4 June 2010.

40. Toutain, J.; Quisefit, J.; Briole, P.; Aloupogiannis, P.; Blanc, P.; Robaye, G. Mineralogy and chemistry of solid aerosols emitted from Mount Etna. Geochem. J. 1995, 29, 163-173. [CrossRef]

41. Stoiber, R.E.; Rose, W.I. The Geochemistry of Central American Volcanic Gas Condensates. GSA Bull. 1970, 81, 2891-2912. [CrossRef]

42. Symonds, R.B.; Reed, M.H.; Rose, W.I. Origin, speciation, and fluxes of trace-element gases at Augustine volcano, Alaska: Insights into magma degassing and fumarolic processes. Geochim. Cosmochim. Acta 1992, 56, 633-657. [CrossRef]

43. Quisefit, J.P.; Bergametti, G.; Tedesco, D.; Pinart, J.; Colin, J.L. Origin of particulate potassium in Mt Etna emissions before and during the 1983 eruption. J. Volcanol. Geotherm. Res. 1988, 35, 111-119. [CrossRef] 
44. Ayris, P.M.; Lee, A.F.; Wilson, K.; Kueppers, U.; Dingwell, D.B.; Delmelle, P. $\mathrm{SO}_{2}$ sequestration in large volcanic eruptions: High-temperature scavenging by tephra. Geochim. Cosmochim. Acta 2013, 110, 58-69. [CrossRef]

45. Van Stempvoort, D.R.; Reardon, E.J.; Fritz, P. Fractionation of sulfur and oxygen isotopes in sulfate by soil sorption. Geochim. Cosmochim. Acta 1990, 54, 2817-2826. [CrossRef]

46. Michalski, G.; Kasem, M.; Rech, J.A.; Adieu, S.; Showers, W.S.; Genna, B.; Thiemens, M. Uncertainties in the oxygen isotopic composition of barium sulfate induced by coprecipitation of nitrate. Rapid Commun. Mass Spectrom. 2008, 22, 2971-2976. [CrossRef] [PubMed]

47. Bao, H. Purifying barite for oxygen isotope measurement by dissolution and reprecipitation in a chelating solution. Anal. Chem. 2006, 78, 304-309. [CrossRef] [PubMed]

48. Le Gendre, E.; Martin, E.; Villemant, B.; Cartigny, P.; Assayag, N. A simple and reliable anion-exchange resin method for sulfate extraction and purification suitable for multiple O- and S-isotope measurements: Anion-exchange method for multiple O- and S-isotope analysis. Rapid Commun. Mass Spectrom. 2017, 31, 137-144. [CrossRef] [PubMed]

49. Schauer, A.J.; Kunasek, S.A.; Sofen, E.D.; Erbland, J.; Savarino, J.; Johnson, B.W.; Amos, H.M.; Shaheen, R.; Abaunza, M.; Jackson, T.L.; et al. Oxygen isotope exchange with quartz during pyrolysis of silver sulfate and silver nitrate: Oxygen isotope exchange during pyrolysis of $\mathrm{Ag}_{2} \mathrm{SO}_{4}$ and $\mathrm{AgNO}_{3}$. Rapid Commun. Mass Spectrom. 2012, 26, 2151-2157. [CrossRef] [PubMed]

50. Pepkowitz, L.; Shirley, E. microdetection of sulfur. Anal. Chem. 1951, 23, 1709-1710. [CrossRef]

51. Farquhar, J.; Peters, M.; Johnston, D.T.; Strauss, H.; Masterson, A.; Wiechert, U.; Kaufman, A.J. Isotopic evidence for Mesoarchaean anoxia and changing atmospheric sulphur chemistry. Nature 2007, 449, 706-709. [CrossRef] [PubMed]

52. Rafter, T.A. Oxygen isotopic composition of sulfates. Part I. A method for the extraction of oxygen and its quantitative conversion to carbon dioxide for isotope radiation measurements. N. Z. J. Sci. 1967, 10, 493-510.

53. Mizutani, Y. An improvement in the carbon-reduction method for the oxygen isotopic analysis of sulphates. Geochem. J. 1971, 5, 69-77. [CrossRef]

54. Bao, H.; Thiemens, M.H. Generation of $\mathrm{O}_{2}$ from $\mathrm{BaSO}_{4}$ using a $\mathrm{CO}_{2}$-laser fluorination system for simultaneous analysis of $\mathrm{d}^{18} \mathrm{O}$ and $\mathrm{d}^{17} \mathrm{O}$. Anal. Chem. 2000, 72, 4029-4032. [CrossRef] [PubMed]

55. Geng, L.; Schauer, A.J.; Kunasek, S.A.; Sofen, E.D.; Erbland, J.; Savarino, J.; Allman, D.J.; Sletten, R.S.; Alexander, B. Analysis of oxygen-17 excess of nitrate and sulfate at sub-micromole levels using the pyrolysis method: Analysis of oxygen-17 excess of nitrate and sulfate. Rapid Commun. Mass Spectrom. 2013, 27, 2411-2419. [CrossRef] [PubMed]

56. Savarino, J.; Alexander, B.; Darmohusodo, V.; Thiemens, M.H. Sulfur and Oxygen Isotope Analysis of Sulfate at Micromole Levels Using a Pyrolysis Technique in a Continuous Flow System. Anal. Chem. 2001, 73, 4457-4462. [CrossRef] [PubMed]

57. Au Yang, D.; Landais, G.; Assayag, N.; Widory, D.; Cartigny, P. Improved analysis of micro- and nanomole-scale sulfur multi-isotope compositions by gas source isotope ratio mass spectrometry: Improved analysis of $\mathrm{S}$ isotopes at micro/nanomole levels by IRMS. Rapid Commun. Mass Spectrom. 2016, 30, 897-907. [CrossRef] [PubMed]

58. Martin, R.S.; Sawyer, G.M.; Spampinato, L.; Salerno, G.G.; Ramirez, C.; Ilyinskaya, E.; Witt, M.L.I.; Mather, T.A.; Watson, I.M.; Phillips, J.C.; et al. A total volatile inventory for Masaya Volcano, Nicaragua. J. Geophys. Res. 2010, 115. [CrossRef]

59. Allen, A.G.; Oppenheimer, C.; Ferm, M.; Baxter, P.J.; Horrocks, L.A.; Galle, B.; McGonigle, A.J.S.; Duffell, H.J. Primary sulfate aerosol and associated emissions from Masaya Volcano, Nicaragua. J. Geophys. Res. Atmos. 2002, 107, 4682. [CrossRef]

60. Cwiertny, D.M.; Young, M.A.; Grassian, V.H. Chemistry and Photochemistry of Mineral Dust Aerosol. Annu. Rev. Phys. Chem. 2008, 59, 27-51. [CrossRef] [PubMed]

61. Sakai, H.; Casadevall, T.J.; Moore, J.G. Chemistry and isotope ratios of sulfur in basalts and volcanic gases at Kilauea volcano, Hawaii. Geochim. Cosmochim. Acta 1982, 46, 729-738. [CrossRef]

62. Allard, P. 13C/12C and 34S/32S ratios in magmatic gases from ridge volcanism in Afar. Nature 1979, 282, 56-58. [CrossRef] 
63. Sakai, H.; Gunnlaugsson, E.; Tòmasson, J.; Rouse, J.E. Sulfur isotope systematics in icelandic geothermal systems and influence of seawater circulation at Reykjanes. Geochim. Cosmochim. Acta 1980, 44, 1223-1231. [CrossRef]

64. Goff, F.; McMurtry, G.M. Tritium and stable isotopes of magmatic waters. J. Volcanol. Geotherm. Res. 2000, 97, 347-396. [CrossRef]

65. Taran, Y.; Gavilanes, J.C.; Cortés, A. Chemical and isotopic composition of fumarolic gases and the $\mathrm{SO}_{2}$ flux from Volcán de Colima, México, between the 1994 and 1998 eruptions. J. Volcanol. Geotherm. Res. 2002, 117, 105-119. [CrossRef]

66. Sakai, H.; Matsubaya, O. Stable isotopic studies of japanese geothermal systems. Geothermics 1977, 5, 97-124. [CrossRef]

67. Giggenbach, W. The chemical and isotopic composition of gas discharges from New Zealand andesitic volcanoes. Bull. Volcanol. 1982, 45, 253-255. [CrossRef]

68. Williams, S.N.; Sturchio, N.C.; Calvache, V.M.L.; Mendez, F.R.; Londoño, C.A.; García, P.N. Sulfur dioxide from Nevado del Ruiz volcano, Colombia: Total flux and isotopic constraints on its origin. J. Volcanol. Geotherm. Res. 1990, 42, 53-68. [CrossRef]

69. Richet, P.; Bottinga, Y.; Javoy, M. A Review of Hydrogen, Carbon, Nitrogen, Oxygen, Sulphur, and Chlorine Stable Isotope Fractionation Among Gaseous Molecules. Annu. Rev. Earth Planet. Sci. 1977, 5, 65-110. [CrossRef]

70. Ohmoto, H.; Rye, R.O. Isotope of sulfur and carbon. In Geochemestry of Hydrothermal Deposits; Barnes, H.L., Ed.; John Wiley \& Sons: Hoboken, NJ, USA, 1979; pp. 509-567.

71. Labidi, J.; Cartigny, P.; Birck, J.L.; Assayag, N.; Bourrand, J.J. Determination of multiple sulfur isotopes in glasses: A reappraisal of the MORB $\delta^{34}$ S. Chem. Geol. 2012, 334, 189-198. [CrossRef]

72. De Hoog, J.C.M.; Taylor, B.E.; van Bergen, M.J. Sulfur isotope systematics of basaltic lavas from Indonesia: Implications for the sulfur cycle in subduction zones. Earth Planet. Sci. Lett. 2001, 189, 237-252. [CrossRef]

73. Martin, E.; Bindeman, I.; Grove, T. The origin of high-Mg magmas in Mt Shasta and Medicine Lake volcanoes, Cascade Arc (California): Higher and lower than mantle oxygen isotope signatures attributed to current and past subduction. Contrib. Miner. Petrol. 2011, 162, 945-960. [CrossRef]

74. Eiler, J. Oxygen isotope variations of basaltic lavas and upper mantle rocks. In Reviews in Mineralogy and Geochemistry; Walley, J.W., Cole, D.R., Eds.; The Mineralogical Society of America: Washington, DC, USA, 2001; Volume 43, pp. 319-364.

75. Bindeman, I.N.; Eiler, J.M.; Wing, B.A.; Farquhar, J. Rare sulfur and triple oxygen isotope geochemistry of volcanogenic sulfate aerosols. Geochim. Cosmochim. Acta 2007, 71, 2326-2343. [CrossRef]

76. De Moor, J.M.; Fischer, T.P.; Hilton, D.R.; Hauri, E.; Jaffe, L.A.; Camacho, J.T. Degassing at Anatahan volcano during the May 2003 eruption: Implications from petrology, ash leachates, and $\mathrm{SO}_{2}$ emissions. J. Volcanol. Geotherm. Res. 2005, 146, 117-138. [CrossRef]

77. Rye, R.O.; Luhr, J.F.; Wasserman, M.D. Sulfur and oxygen isotopic systematics of the 1982 eruptions of El Chichón Volcano, Chiapas, Mexico. J. Volcanol. Geotherm. Res. 1984, 23, 109-123. [CrossRef]

78. Savarino, J.; Bekki, S.; Cole-Dai, J.H.; Thiemens, M.H. Evidence from sulfate mass independent oxygen isotopic compositions of dramatic changes in atmospheric oxidation following massive volcanic eruptions. J. Geophys. Res. Atmos. 2003, 108. [CrossRef]

79. Baroni, M. Etude des Anomalies Isotopiques du Soufre et de L'oxygène Dans le Sulfate D'origine Volcanique Enregistré dans les Archives Glaciaires; Univeristé Joseph Fourier: Grenoble, France, 2006.

80. Baroni, M.; Thiemens, M.H.; Delmas, R.J.; Savarino, J. Mass-Independent Sulfur Isotopic Compositions in Stratospheric Volcanic Eruptions. Science 2007, 315, 84-87. [CrossRef] [PubMed]

81. Baroni, M.; Savarino, J.; Cole-Dai, J.; Rai, V.K.; Thiemens, M.H. Anomalous sulfur isotope compositions of volcanic sulfate over the last millennium in Antarctic ice cores. J. Geophys. Res. Atmos. 2008, 113, D20112. [CrossRef]

82. Gautier, E. Empreinte Isotopique et Histoire du Volcanisme Stratosphérique des 2600 Dernières Années, Enregistrées à Dome C, Antarctique; Université Grenoble Alpes: Grenoble, France, 2015.

83. Cole-Dai, J.; Ferris, D.; Lanciki, A.; Savarino, J.; Baroni, M.; Thiemens, M.H. Cold decade (AD 1810-1819) caused by Tambora (1815) and another (1809) stratospheric volcanic eruption. Geophys. Res. Lett. 2009, 36. [CrossRef] 
84. Miyoshi, T.; Sakai, H.; Chiba, H. Experimental study of sulfur isotope fractionation factors between sulfate and sulfide in high temperature melts. Geochem. J. 1984, 18, 75-84. [CrossRef]

85. Hoefs, J. Stable Isotope Geochemistry; Springer: Berlin/Heidelberg, Germany, 2015.

86. Farquhar, J.; Johnston, D.T.; Wing, B.A. Implications of conservation of mass effects on mass-dependent isotope fractionations: Influence of network structure on sulfur isotope phase space of dissimilatory sulfate reduction. Geochim. Cosmochim. Acta 2007, 71, 5862-5875. [CrossRef]

87. Ono, S.; Wing, B.; Johnston, D.; Farquhar, J.; Rumble, D. Mass-dependent fractionation of quadruple stable sulfur isotope system as a new tracer of sulfur biogeochemical cycles. Geochim. Cosmochim. Acta 2006, 70, 2238-2252. [CrossRef]

88. Martin, R.S.; Mather, T.A.; Pyle, D.M. High-temperature mixtures of magmatic and atmospheric gases. Geochem. Geophys. Geosyst. 2006, 7, Q04006. [CrossRef]

89. Roberts, T.J.; Braban, C.F.; Martin, R.S.; Oppenheimer, C.; Adams, J.W.; Cox, R.A.; Jones, R.L.; Griffiths, P.T. Modelling reactive halogen formation and ozone depletion in volcanic plumes. Chem. Geol. 2009, 263, 151-163. [CrossRef]

90. Roberts, T.J.; Martin, R.S.; Jourdain, L. Reactive bromine chemistry in Mount Etna's volcanic plume: The influence of total $\mathrm{Br}$, high-temperature processing, aerosol loading and plume-air mixing. Atmos. Chem. Phys. 2014, 14, 11201-11219. [CrossRef]

91. Gerlach, T.M. Volcanic sources of tropospheric ozone-depleting trace gases. Geochem. Geophys. Geosyst. 2004, 5. [CrossRef]

92. Lee, C.C.-W.; Savarino, J.H.; Cachier, H.; Thiemens, M.H. Sulfur (32S, 33S, 34S, 36S) and oxygen $(16 \mathrm{O}, 17 \mathrm{O}, 18 \mathrm{O})$ isotopic ratios of primary sulfate produced from combustion processes. Tellus $B$ 2002, 54, 193-200. [CrossRef]

93. Belo, L.P.; Elliott, L.K.; Stanger, R.J.; Spörl, R.; Shah, K.V.; Maier, J.; Wall, T.F. High-Temperature Conversion of $\mathrm{SO}_{2}$ to $\mathrm{SO}_{3}$ : Homogeneous Experiments and Catalytic Effect of Fly Ash from Air and Oxy-fuel Firing. Energy Fuels 2014, 28, 7243-7251. [CrossRef]

94. Ono, S. Photochemistry of Sulfur Dioxide and the Origin of Mass-Independent Isotope Fractionation in Earth's Atmosphere. Annu. Rev. Earth Planet. Sci. 2017, 45, 301-329. [CrossRef]

95. Jenkins, K.A.; Bao, H. Multiple oxygen and sulfur isotope compositions of atmospheric sulfate in Baton Rouge, LA, USA. Atmos. Environ. 2006, 40, 4528-4537. [CrossRef]

96. Lee, C.C.-W.; Thiemens, M.H. The $\delta^{17} \mathrm{O}$ and $\delta^{18} \mathrm{O}$ measurements of atmospheric sulfate from a coastal and high alpine region: A mass-independent isotopic anomaly. J. Geophys. Res. Atmos. 2001, 106, 17359-17373. [CrossRef]

97. Li, X.; Bao, H.; Gan, Y.; Zhou, A.; Liu, Y. Multiple oxygen and sulfur isotope compositions of secondary atmospheric sulfate in a mega-city in central China. Atmos. Environ. 2013, 81, 591-599. [CrossRef]

98. Carn, S.A.; Clarisse, L.; Prata, A.J. Multi-decadal satellite measurements of global volcanic degassing. J. Volcanol. Geotherm. Res. 2016, 311, 99-134. [CrossRef]

99. Yang, K.; Krotkov, N.A.; Krueger, A.J.; Carn, S.A.; Bhartia, P.K.; Levelt, P.F. Improving retrieval of volcanic sulfur dioxide from backscattered UV satellite observations. Geophys. Res. Lett. 2009, 36, L03102. [CrossRef]

100. Galeazzo, T.; Bekki, S.; Martin, E. Modeling the Pathways of Generation of O-MIF in Tropospheric Sulfates; GOLDSCHMIDT: Paris, France, 2017.

101. Kroll, J.H.; Cross, E.S.; Hunter, J.F.; Pai, S.; Wallace, L.M.M.; Croteau, P.L.; Jayne, J.T.; Worsnop, D.R.; Heald, C.L.; Murphy, J.G.; et al. Atmospheric Evolution of Sulfur Emissions from Kîlauea: Real-Time Measurements of Oxidation, Dilution, and Neutralization within a Volcanic Plume. Environ. Sci. Technol. 2015, 49, 4129-4137. [CrossRef] [PubMed]

102. Dupart, Y.; King, S.M.; Nekat, B.; Nowak, A.; Wiedensohler, A.; Herrmann, H.; David, G.; Thomas, B.; Miffre, A.; Rairoux, P.; et al. Mineral dust photochemistry induces nucleation events in the presence of $\mathrm{SO}_{2}$. Proc. Natl. Acad. Sci. USA 2012, 109, 20842-20847. [CrossRef] [PubMed]

103. Vallyathan, V.; Shi, X.; Dalal, N.S.; Irr, W.; Castranova, V. Generation of Free Radicals from Freshly Fractured Silica Dust: Potential Role in Acute Silica-induced Lung Injury. Am. Rev. Respir. Dis. 1988, 138, 1213-1219. [CrossRef] [PubMed]

104. Konecny, R. Reactivity of Hydroxyl Radicals on Hydroxylated Quartz Surface. 1. Cluster Model Calculations. J. Phys. Chem. B 2001, 105, 6221-6226. [CrossRef] 
105. Narayanasamy, J.; Kubicki, J.D. Mechanism of Hydroxyl Radical Generation from a Silica Surface: Molecular Orbital Calculations. J. Phys. Chem. B 2005, 109, 21796-21807. [CrossRef] [PubMed]

106. Von Glasow, R.; Sander, R.; Bott, A.; Crutzen, P.J. Modeling halogen chemistry in the marine boundary layer 2. Interactions with sulfur and the cloud-covered MBL. J. Geophys. Res. Atmos. 2002, 107, 4323. [CrossRef]

107. Roberts, T.J.; Jourdain, L.; Griffiths, P.T.; Pirre, M. Re-evaluating the reactive uptake of HOBr in the troposphere with implications for the marine boundary layer and volcanic plumes. Atmos. Chem. Phys. 2014, 14, 11185-11199. [CrossRef]

108. McCormick, M.P.; Thomason, L.W.; Trepte, C.R. Atmospheric effects of the Mt Pinatubo eruption. Nature 1995, 373, 399-404. [CrossRef]

109. Castellano, E.; Becagli, S.; Jouzel, J.; Migliori, A.; Severi, M.; Steffensen, J.P.; Traversi, R.; Udisti, R. Volcanic eruption frequency over the last $45 \mathrm{ky}$ as recorded in Epica-Dome $\mathrm{C}$ ice core (East Antarctica) and its relationship with climatic changes. Glob. Planet. Chang. 2004, 42, 195-205. [CrossRef]

110. Cole-Dai, J.; Mosley-Thompson, E.; Wight, S.P.; Thompson, L.G. A 4100-year record of explosive volcanism from an East Antarctica ice core. J. Geophys. Res. Atmos. 2000, 105, 24431-24441. [CrossRef]

111. Delmas, R.J.; Kirchner, S.; Palais, J.M.; Petit, J.-R. 1000 years of explosive volcanism recorded at the South Pole. Tellus B 1992, 44, 335-350. [CrossRef]

112. Langway, C.C.; Osada, K.; Clausen, H.B.; Hammer, C.U.; Shoji, H. A 10-century comparison of prominent bipolar volcanic events in ice cores. J. Geophys. Res. Atmos. 1995, 100, 16241-16247. [CrossRef]

113. Legrand, M.; Delmas, R.J. A 220-year continuous record of volcanic $\mathrm{H}_{2} \mathrm{SO}_{4}$ in the Antarctic ice sheet. Nature 1987, 327, 671-676. [CrossRef]

114. Hattori, S.; Schmidt, J.A.; Johnson, M.S.; Danielache, S.O.; Yamada, A.; Ueno, Y.; Yoshida, N. SO photoexcitation mechanism links mass-independent sulfur isotopic fractionation in cryospheric sulfate to climate impacting volcanism. Proc. Natl. Acad. Sci. USA 2013, 110, 17656-17661. [CrossRef] [PubMed]

115. Danielache, S.O.; Hattori, S.; Johnson, M.S.; Ueno, Y.; Nanbu, S.; Yoshida, N. Photoabsorption cross-section measurements of32S, 33S, 34S, and 36S sulfur dioxide for the B1B1-X1A1 absorption band. J. Geophys. Res. Atmos. 2012, 117, D24301. [CrossRef]

116. Danielache, S.O.; Eskebjerg, C.; Johnson, M.S.; Ueno, Y.; Yoshida, N. High-precision spectroscopy of 32S, 33S, and 34 S sulfur dioxide: Ultraviolet absorption cross sections and isotope effects. J. Geophys. Res. Atmos. 2008, 113, D17314. [CrossRef]

117. Whitehill, A.R.; Jiang, B.; Guo, H.; Ono, S. $\mathrm{SO}_{2}$ photolysis as a source for sulfur mass-independent isotope signatures in stratospehric aerosols. Atmos. Chem. Phys. 2015, 15, 1843-1864. [CrossRef]

118. Brasseur, G.P.; Solomon, S. Aeronomy of the Middle Atmosphere, Chemistry and Physics of the Stratosphere and Mesosphere; Springer: Dordrecht, The Netherlands, 2005.

119. Bao, H.; Yu, S.; Tong, D.Q. Massive volcanic $\mathrm{SO}_{2}$ oxidation and sulphate aerosol deposition in Cenozoic North America. Nature 2010, 465, 909-912. [CrossRef] [PubMed]

120. Fraser, W.; Lomax, B.; Beerling, D.; James, D.; Pyle, J.; Self, S.; Sephton, M.; Wellman, C. Episodic perturbations of end-Permian atmosphere recorded in plant spore chemistry. In Proceedings of the EGU General Assembly 2016, Vienna, Austria, 17-22 April 2016; Volume 18, p. EPSC2016-17251.

121. Lomax, B.H.; Fraser, W.T. Palaeoproxies: Botanical monitors and recorders of atmospheric change. Palaeontology 2015, 58, 759-768. [CrossRef]

122. Shepherd, T.G. Issues in stratosphere-troposphere coupling. J. Meteorol. Soc. Jpn. 2002, 80, 769-792. [CrossRef]

123. Robock, A. Climatic impact of volcanic emissions. In State of the Planet; Sparks, R.S.J., Hawkesworth, C.J., Eds.; American Geophysical Union: Washington, DC, USA, 2004; Volume 19.

124. Bekki, S. Oxidation of Volcanic $\mathrm{SO}_{2}$ : A Sink for Stratospheric $\mathrm{OH}$ and $\mathrm{H}_{2} \mathrm{O}$. Geophys. Res. Lett. 1995, 22, 913-916. [CrossRef]

(C) 2018 by the author. Licensee MDPI, Basel, Switzerland. This article is an open access article distributed under the terms and conditions of the Creative Commons Attribution (CC BY) license (http:/ / creativecommons.org/licenses/by/4.0/). 